\title{
How to decrease pharmaceuticals in the environment? A review
}

\author{
Magda Caban $^{1}\left[\right.$. Piotr Stepnowski ${ }^{1}$
}

Received: 27 September 2020 / Accepted: 20 January 2021 / Published online: 30 March 2021

(c) The Author(s) 2021

\begin{abstract}
The global problem of the presence of human and veterinary pharmaceuticals in the environment is under investigation. Despite the increase in the knowledge of its sources, fates and impacts, the assessment of risks and the derived prevention actions are limited to single cases. The predicted increasing trend in the usage of pharmaceuticals forces the various parties involved to think about comprehensive mitigation actions. There are many areas of daily human life and industrial operations where such actions should take place. Thereby, in the presented review, such actions were summarized and divided into the following groups: A. design, synthesis and production of pharmaceuticals, B. prescription, sales and waste handling, C. control of the sources with advanced technologies. As the total amount of proposed actions was found to be quite high, a ranking according to the term of effects was proposed using the pyramid of needs. The advantages of actions taken in the first steps of the pharmaceutical life cycle (acting on the upstream) over end-of-pipe actions and the application of advanced technologies (the downstream option) were discussed, with reference to expert opinions.
\end{abstract}

Keywords Pharmaceutical residues · Pollution management $\cdot$ Pharmaceutical life cycle $\cdot$ Antibiotic resistance · Advanced treatment technologies

$\begin{array}{ll}\text { Abbreviations } \\ \text { EDCs } & \text { Endocrine Distrupting Chemicals } \\ \text { NSAIDs } & \begin{array}{l}\text { Non-steroidal anti-inflammatory drugs } \\ \text { OECD }\end{array} \\ & \begin{array}{l}\text { Organization for Economic Co-operation and } \\ \text { Development }\end{array} \\ \text { WHO } & \text { World Health Organization } \\ \text { WWTP } & \text { Wastewater Treatment Plant }\end{array}$

\section{Introduction}

The first reports on the presence of pharmaceuticals in wastewater and natural water were published in 1977-1978 (Hignite and Azarnoff 1977; Cardoso et al. 2014). Since then, knowledge of the sources, fate and ecotoxicology of pharmaceuticals has started to advance. It has been well confirmed that pharmaceuticals are present all over the world in groundwater, surface water, wastewater, soils and biota (aus der Beek et al. 2016; Łukaszewicz et al. 2018; Patel

Magda Caban

magda.caban@ug.edu.pl

1 Department of Environmental Analysis, Faculty of Chemistry, University of Gdansk, ul. Wita Stwosza 63, 80-308 Gdańsk, Poland et al. 2019). In general, many sources and pathways of pharmaceuticals have been identified (aus der Beek et al. 2016; Puckowski et al. 2016). Residential wastewater is often presented as the primary source; thereby, pharmaceuticals can be used as markers of surface and groundwater pollution by domestic wastewater (Tran et al. 2015b). Nevertheless, non-wastewater emission pathways are also important $(\mathrm{Bu}$ et al. 2016), for example, aquacultures and wastewaters from livestock. Furthermore, in the case of some groups of pharmaceuticals, pathways other than municipal wastewater may dominate. A good example are antibiotics used in animal treatments. Antibiotics are of particular concern due to bacterial resistance. After several years of monitoring and ecotoxicological studies, pharmaceuticals have graduated to the state of being an emerging problem according to such institutions as the European Commission (Deloitte Sustainability 2018) and HELCOM (International Initiative on Water Quality-IIWQ 2017). The bibliometric analysis of the issue of pharmaceuticals in the environment (Daughton 2016) takes an interest not only in scientific articles and books, but also conference proceedings, TV programs, new media, websites and others. This proves that there is global concern regarding the problem, not only in the field of science.

The problem of environment contamination by pharmaceuticals is complex, not only because of various sources 
and complex fates (Bagnis et al. 2018), but also the numerous medical compounds in use. Of the total number of pharmaceutically active substances-11,926 (https://www. drugbank.ca/stats), 713 substances were tested in wastewater and environmental samples (aus der Beek et al. 2016). For $88 \%$ of medicines, there are no environmental toxicity data (OECD 2019). It is therefore possible that the so-called Matthew effect is obtained (a psychosocial phenomenon sometimes informally referred to as the "bandwagon effect" or "iceberg effect")—-"decisions that base the selection of target stressors in environmental monitoring surveys on whether they have been identified in prior studies, rather than considering the possibility that additional, but previously unreported, stressors might also play important roles in an exposure scenario" (Daughton 2014). Furthermore, the publicly available data of pharmaceutical consumption are unavailable for most countries, as well as the real environmental concentrations (aus der Beek et al. 2016). Bearing in mind the fact that: A. pharmaceuticals have been known to be present globally for more than forty years and they cause chronic exposure for water organisms, B. there are various sources of each class of pharmaceuticals, C. there is an increasing global trend in the use of pharmaceuticals, D. the presence of pharmaceuticals can induce changes in the environment, E. it is probable that the problem is underestimated due to the "Matthew Effect"-pharmaceuticals are an emerging problem, for which there is no single solution.

The main objective of this review was to present a variety of actions to minimize the problem of the presence of pharmaceuticals in the environment, which should be implemented for the comprehensive management of the problem, with emphasis on downstream actions. Thereby, despite the pharmaceuticals used in the human medicine, those used for animal (in this for pets) and plants treatment were the subject, despite the general opinion of its minor contribution to environment pollution. Previously published reviews presenting minimalization possibilities for pharmaceuticals (Daughton 2003; Kümmerer 2009; Ebert et al. 2015; Caldwell et al. 2016; OECD 2019; Patel et al. 2019), and micropollutants in general (Schirmer and Schirmer 2008), were also referred. Thanks to this the comprehensive review was carried out. The most effective action, which is not presented here, but is intuitive, is prevention by increasing the wellness, hygiene standards and conditions of humans and animals.

The information presented in this review relates to the life cycle of pharmaceuticals (Fig. 1). The review starts with a presentation of the upstream possibilities: design, synthesis, production, prescription, sales and waste handling. Then, the control of sources (aquaculture, hospital wastewaters, wastewater from livestock, residential and industrial wastewaters, runoff, leaching from landfills, the accidental and intentional introduction of untreated wastewaters) and advanced treatment technologies were highlighted as downstream actions. The reviews focusing on the mentioned areas were cited for readers interested in the details of the proposed solutions.

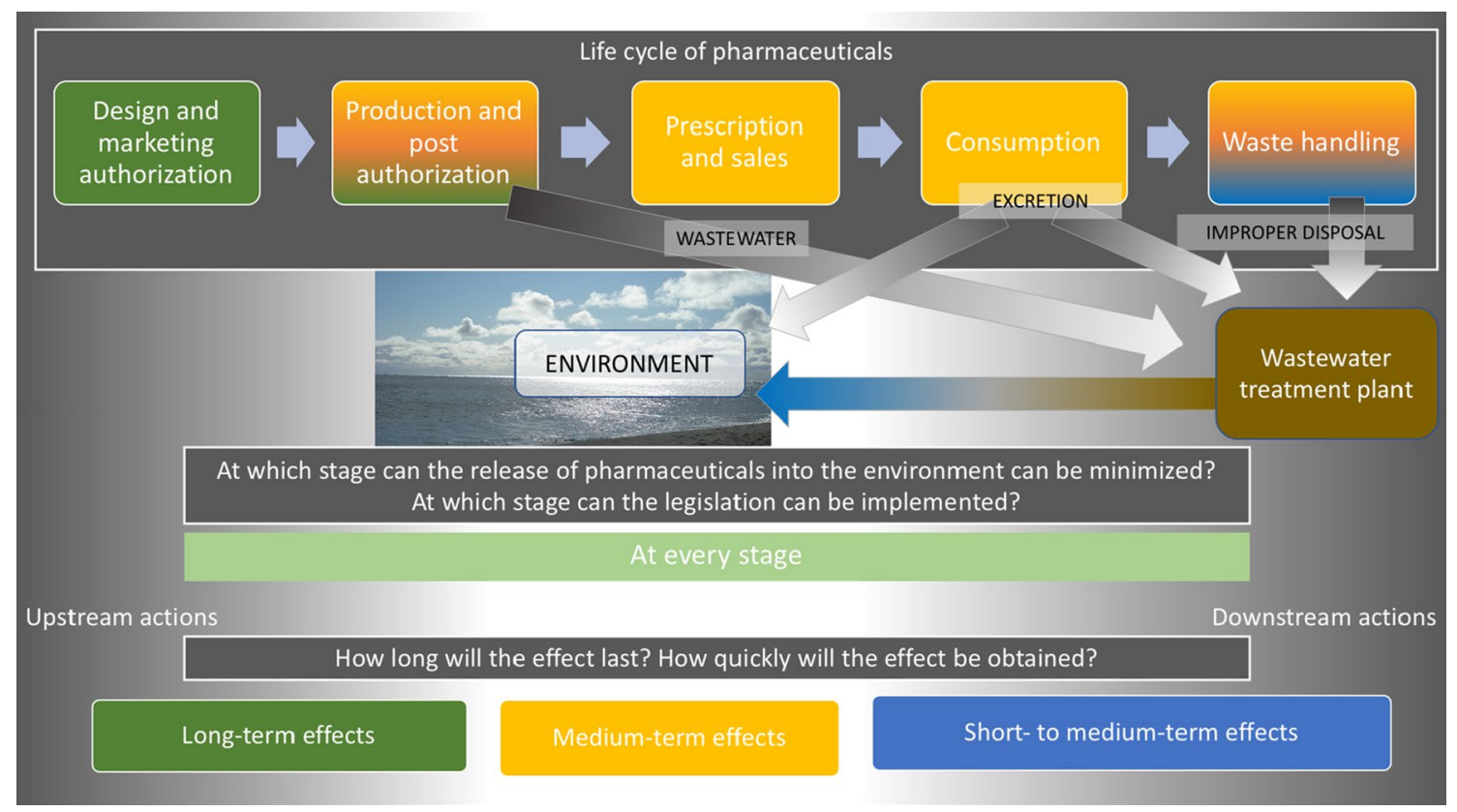

Fig. 1 Overview of the pharmaceutical life cycle with relation to the possibilities of minimizing their presence in the environment 


\section{Design and production of pharmaceuticals}

The use of pharmaceuticals will grow for several reasons (OECD 2019): the global trend of an increase in the age and life span of populations, economic growth, intensified livestock practices, climate changes which exacerbate existing diseases (for example, malaria and dengue fever (Cavicchioli et al. 2019)). The global annual growth rate of the pharmaceutical industry is estimated to be $6.5 \%$ (United Nations Environment Programme 2019). Thereby, several actions toward reduction should be taken in the design, synthesis and production of pharmaceuticals.

The synthesis of eco-friendly pharmaceuticals is a concept which assumes that pharmaceuticals, after excretion, will easily degrade and be less toxic for aquatic organisms, and this can be done by manipulation of the chemical structure. This improvement should not change the active ingredients during shelf storage and not change the mechanism of action. The trigger for degradation could be a change in the $\mathrm{pH}$ or UV. The same concept is proposed for other pollutants with the tenth principle of green chemistry, which is "Design for Degradation." For example, the re-designing of propranolol (beta-blocker) affects quicker aerobic biodegradation (Rastogi et al. 2015). The concept of "benignby-design pharmacology" and green chemistry is an area of industry which is attractive from the environmental point of view (Daughton 2003; Kümmerer 2009; Leder et al. 2015).

Furthermore, the design of new active substances should be coupled with two main features: higher bio-availability and higher selectivity of action. The designation of new forms of pharmaceutical application can regulate or accelerate the rate of absorption. Every concept of enhancing the bio-availability and selectivity of pharmaceuticals will be related with the fact that lower doses are used. Another solution is the "smart drug" concept, which aims to produce pharmaceuticals that go into a given receptor.

The new term of Smart Drug Delivery Systems is coupled with innovations in pharmaceutical delivery, such as carbon nanotubes, dendrimers, micelles, liposomes, quantum dots, SPIONS, gold nanoparticles and mesoporous silica nanoparticles (Hossen et al. 2018). All of these can be named nanocarriers and their invention follows the very fresh concept of nanochemistry. The boundaries and opportunities in the field of smart nanoparticles for pharmaceutical delivery are still under investigation (Sercombe et al. 2015). From the other side, the caution in use of nanoparticles should be taken currently, because its impact into environment is still under assessment (Bundschuh et al. 2018). One idea is the well-known solution of the preparation of liposomes, which are highly compatible with cell barriers. Liposomes are spherical colloidal systems consisting of a phospholipid bilayer shell with an aqueous internal core ( $\mathrm{Li}$ et al. 2018;
Okamoto et al. 2018). They have been known and used as a solution for 50 years, not only in pharmacy, but also in food production, cosmetics and agriculture. Despite their increasing bio-availability, the toxicity of pharmaceuticals can be lower thanks to covering the active substance with a natural barrier. This is used especially in the application of pharmaceuticals for cancer treatment (Soe et al. 2018). Another solution is to use exosomes (Qu et al. 2018; Shyong et al. 2018) or exosome-mimicking liposomes ( $\mathrm{Lu}$ et al. 2018). Exosomes are naturally occurring elements of cells, which are used, for example, in cancer therapy, as tumors have a high potential for exosome sorption (Bastos et al. 2018). In the case of macromolecules, special dermal and transdermal delivery methods can be used (Münch et al. 2017). Even more innovations have been presented in recent years, and their description is out of the scope of this review (the advised journals are the Advanced Drug Delivery Reviews and the Journal of Controlled Release).

An example of increasing absorption is the production of new salts of active substances, which can easily transfer through skin barriers. Such salts have an ionic liquid character (Wiest et al. 2017; Egorova and Ananikov 2018). For example, diclofenac can be synthetized as a diethylamine salt with high bio-availability (dermal delivery) (Goh and Lane 2014). The strengths and weaknesses of ionic liquids for pharmaceutical application were presented by A. Balk et al. (Balk et al. 2015).

Another idea is the synthesis of prodrugs, which start to be active in-situ, for example, by the fact that some cells have specific enzymes which can release the target pharmaceuticals or change their structure into active forms (Walther et al. 2017). This kind of solution is used in cancer therapy. For example, capecitabine is a precursor of 5-fluorouracil, a popular anticancer agent, whose reactivity is obtained mainly in tumor cells. Chemotherapy agent-unsaturated fatty acid prodrugs are an interesting solution, as such chemicals create nanoparticles similar to liposomes (Sun et al. 2017). A popular reaction which is often used is deacetylation (for example, the release of morphine from heroin in the brain). The presented solutions can be categorized as examples of "click chemistry."

One action which seems possible to perform is the production of only one enantiomer of a pharmaceutical, which is active (more than $50 \%$ of pharmaceuticals in current use are chiral compounds (Ribeiro et al. 2012; Sanganyado et al. 2017)). Such a situation occurs, for example, with some pesticides, such as metachlor (O'Connell et al. 1998). In practice, enantioselective synthesis is often unavailable, and the purification of the enantiomer mixture is hard to perform and time-/energy-consuming. Nevertheless, the number of new pharmaceuticals sold as pure enantiomers increased within the last ten years (FDA data 2017 (Sanganyado et al. 2017)). A review on chiral pharmaceuticals in the environment 
(sources, health risks, remediation and more) can be found in (Zhou et al. 2018).

In the case of antibiotics, alternatives can be used, for example, enzymes, peptides, vaccines, antibodies, phage therapies, immune stimulation, prebiotics, probiotics, essential oils and herbal medicines (Czaplewski et al. 2016; Ioannou et al. 2018; Omonijo et al. 2018). The development of alternatives to antibiotics is especially important in this era of antibiotic resistance (World Health Organization 2014; Uppu et al. 2015). One option is the synthesis of bacteriaspecific antibiotics.

Furthermore, expiration dates need to be re-evaluated. Most producers deliberately reduce these or use a standard value of one year. Another issue is the environmental sustainability of materials which are used in pharmaceutical packaging (Raju et al. 2016). Such actions would reduce pharmaceutical waste, and in parallel, the cost incurred by patients.

\section{Prescription and sales of pharmaceuticals}

The prescription and sales of pharmaceuticals increase each year and will be even greater in the upcoming years (Evaluate Pharma 2017). In the USA, in the last decade, the number of prescriptions increased by $85 \%$, despite the fact that the population increased by $21 \%$ (Carr 2017). More than $50 \%$ of Americans regularly take prescription pharmaceuticals, often from more than one specialist.

The pharmaceuticals are often wrongly prescribed or chosen when the diagnosis of the pathogen is at a low level. The situation when a patient takes medicines "just in case" is popular, and is caused by both specialist and patient pressure. A good example is the situation when antibiotics are offered for influenza, despite the fact that a viral disease cannot be treated by antibiotics. The use of antibiotics for already antibiotic-resistant bacteria (especially in veterinary medicine) should be eliminated. The WHO estimation is that even $50 \%$ of antibiotics are misused (World Health Organization 2014). In Lebanon, about $50 \%$ of antibiotics are used without a prescription, thereby without a diagnosis at the same time (Jamhour et al. 2017). Prescribing errors may be numerous in the elderly (Costa-Font and Gemmill Toyama 2011; Mohan et al. 2014). Biosensors and quick tests are already available for fast and reliable pathogen detection (Singh et al. 2014; Nasseri et al. 2018). Such tests could be easily available both for specialists and patients.

The abuse of and addiction to pharmaceuticals are more often observed, especially regarding painkillers, psychiatric drugs and sedatives (Costa-Font and Gemmill Toyama 2011; Borgschulte et al. 2018). Furthermore, overdosing on prescription pharmaceuticals can be caused by differences between the established dose and the effective dose. In extreme cases, the established dose can be even an order of magnitude greater than the active dose. Precise, individual and personalized treatment is needed to reduce overdosing. Pharmaceutical doses should be calculated individually per patient mass, sex, health, age, genetics and sensitivity. Such a solution is already starting around the world (Cree 2013; Cutica et al. 2014; Cenci 2016). Less hazardous active ingredients that are equally fit to cure the disease need to be proposed during prescribing.

Moreover, there is also a trend for self-medication, caused by a lack of trust between patient and doctor, but also a person's educational level, and the development of the country (Jamhour et al. 2017; Smirnova and Owens 2017). Self-medication is mostly connected with pain relief and is unrated (Mehuys et al. 2019). Self-medication with antibiotics has become a significant factor driving antibiotic resistance (Torres et al. 2018). Furthermore, the pressure on doctors from patients can lead to overdoses, also in veterinary medicine (Ekakoro and Okafor 2018).

The control of medical prescriptions is important. Computational systems, which are already in use in several countries, are helpful, but can still have limitations (Alhanout et al. 2017). The control of prescriptions is especially important in the case of older persons, who often take the same active substance supplied by a different specialist. Improvements in the prescription of pharmaceuticals are an essential goal for the current health system (Costa-Font and Gemmill Toyama 2011). More importantly, the prevention of diseases is the best solution for a reduction in pharmaceuticals in the environment. An analysis of demographic structures and the prediction of trends therein would be beneficial for effective long-term strategy building.

The sales of pharmaceuticals can be improved by the following activities:

- The sale of a specific number of pills or mass of active substances, instead of unified bulk packaging. This is especially important for pharmaceuticals with a short expiration date, for example, aspirin. Small-quantity trial and installment dispensing is also a rational option.

- The appropriate packaging - the visibility of the expiration date should be improved, as well as the dosing. Furthermore, information on the necessity of returning expired pharmaceuticals to special places (mostly pharmacies) should be included and highlighted on the information leaflet attached to the packaging. The needs of patients should be taken into account in packaging innovations (Carli Lorenzini et al. 2018). There is a need for the use of pictograms for medicines intended for older people ( $\mathrm{Ng}$ et al. 2017).

- An electronic and available online system of the history of patient treatment, to avoid the situation where different specialists prescribed the same active substance, but 
with different names or forms of application (for example pills and syrup). Furthermore, such a history could avoid the prescription of already tested, but ineffective, pharmaceuticals. This could also improve the search for abuse and addiction, or even combat the illegal re-sale of prescribed pharmaceuticals. Furthermore, prescriptions should have a limited validity.

- A system for the return of unused pharmaceuticals to the pharmacy. A patient whose treatment was shorter than planned has leftover medicines which can be used by other people. Furthermore, this avoids the future use of this pharmaceutical without specialist consultation.

- Improving the medication packaging. The aim of this is to extend the expiration date, for example, by separately packing portions of pills and ensuring better prevention against humidity.

- The unification of pharmaceutical names for those products which contain the same active substance, and for the patient purchasing them without knowledge of the content. A good example is eye drops, as there are several different names on the market with the same active substance.

- Eco-labeling-generally, its use improves consumer choice and awareness, finally improving social welfare (Li 2020). Until today, eco-labeling has not been used by any certification organization. Eco-labeling should be used for the active substance and the packaging material.

- Restrictions in the advertising of pharmaceuticals, especially for painkillers and "lifestyle drugs." Lifestyle pharmaceuticals are those used for the treatment of non-lifethreatening and non-painful disorders, for example, acne, baldness, wrinkles and erectile dysfunction. The other definition is pharmaceuticals used to "satisfy a non-medical or non-health-related goal" (Flower 2004). Most of these are used as self-medication. As examples, sildenafil (Viagra), bupropion (managing nicotine addiction) and methadone (opiate substitute) can be listed. Image and Performance Enhancement Drugs (IPEDs) are a wide range of substances that are taken to alter body image and/or performance (Begley et al. 2017), so their definition is close to "lifestyle drugs." They are legal, but often illicitly manufactured and sourced. Non-medical use (NMU) pharmaceuticals involve the consumption of prescription or over-the-counter (OTC) pharmaceuticals for non-therapeutic purposes or those other than directed by a healthcare specialist (the best example are opioids) (Hulme et al. 2018).

- Control of internet sales of pharmaceuticals. Often large packages are available at a low price and with unknown purity. IPEDs are mostly purchased online (van de Ven and Koenraadt 2017). Psychiatric pharmaceuticals (for example, amphetamine, lorazepam, diazepam, methyl- phenidate and lisdexamfetamine, all with a high risk of abuse) are increasingly found online in illegal pharmacies (Monteith and Glenn 2018). NMU pharmaceuticals are found to be primarily sourced through informal exchanges between friends and family (Hulme et al. 2018).

- Control of the black market of pharmaceuticals. Press releases have described that about $25 \%$ of pharmaceuticals are sold on the black market (calculations of the World Anti-Doping Agency), with a high percentage of anabolic androgenic steroids (Coopman and Cordonnier 2012; Neves and Caldas 2017). The purchasing of medicines on the black market is often a result of high costs on the legal market. In Africa, even $20 \%$ of veterinary pharmaceuticals used come from illegal sources. A report on illegal veterinary pharmaceuticals and ways to avoid them can be found in the literature (Regional Workshop for OIE National Focal Points 2017). In parallel, the sale of counterfeit pharmaceuticals should also be controlled (Almuzaini et al. 2013).

The key to minimizing the use of lifestyle drugs, IPEDs and the black market is to increase awareness in consumers regarding the risks and side effects of self-medication (for example, here for anabolics (Lusetti et al. 2018)). In this concept, the minimalization of pharmaceuticals in the environment is parallel with increasing sensible and safe medication and the reduction in side effects.

The problem which needs to be solved is the high number of leftover medications (it is estimated that even $1 / 3$ of prescribed medications end as waste (OECD 2019)). Here, we can refer to the analysis of Daughton and Ruhoy (Daughton and Ruhoy 2011), in which approaches were presented for preventing the generation of leftover pharmaceuticals.

\section{Source control and advanced treatment technologies}

\section{Waste handling by consumers}

One of the reasons for the presence of pharmaceuticals in municipal wastewater is improper disposal by flushing down sinks or toilets. Table 1 presents studies of the handling and disposing practices of households for unused and expired pharmaceuticals. The review from 2011 (Tong et al. 2011a) presents more examples and confirms the major observation presented in Table 1 that most unwanted pharmaceuticals end up in the garbage, sink or toilet. The relative importance of this source of pharmaceuticals compared to excretion is unknown (Kotchen et al. 2009). A study from the UK on the distribution of pharmaceuticals, which takes into 
Table 1 Household habits in pharmaceutical disposal

\begin{tabular}{|c|c|c|}
\hline Type of survey (year, country) & Main results & References \\
\hline $\begin{array}{l}\text { In-street survey, } 1865 \text { respondents } \\
\text { from seven sites }(2015-2016 \text {, } \\
\text { China) }\end{array}$ & $\begin{array}{l}75 \% \text { of the population has unwanted pharmaceuticals at home ( } 182 \mathrm{~g} \text { per } \\
\text { capita); } \\
54 \% \text { of the population disposes of unwanted pharmaceuticals in the garbage, } \\
4 \% \text { down the toilet }\end{array}$ & (Chung and Brooks 2019) \\
\hline 358 university students (2017, USA) & $\begin{array}{l}61 \% \text { of the population has unused pharmaceuticals; } \\
\text { disposal by municipal waste }(25 \%) \text {, toilet }(1 \%) \text {, take-back programs }(2 \%) \text {; } \\
\text { a large number of students have medicines that need to be disposed of in the } \\
\text { near future }\end{array}$ & (Vatovec et al. 2017) \\
\hline 398 participants $(2010,2011$, Ireland) & $\begin{array}{l}88 \% \text { of the respondents have unused pharmaceuticals at home; } \\
\text { disposal through household waste }(51 \%) \text {, sink }(29 \%) \text {, toilet }(14 \%) \text {, other }\end{array}$ & (Vellinga et al. 2014) \\
\hline 1121 participants (2016, Turkey) & $\begin{array}{l}41 \% \text { of the respondents have unused pharmaceuticals at home; } \\
\text { disposal practice: take-back program (32\%), donation to healthcare facilities } \\
(34 \%) \text {, disposal in the garbage/sink/toilet (34\%) }\end{array}$ & (Akici et al. 2018) \\
\hline 452 participants (2008, New Zealand) & $\begin{array}{l}\text { Disposal practices: disposal in the garbage/sink/toilet }(55 \%) \text {, return to the } \\
\text { pharmacy }(17 \%)\end{array}$ & (Braund et al. 2009) \\
\hline
\end{tabular}

account the excretion rate, disposal habits and efficiency of WWTP elimination, supports the statement that the disposal of pharmaceuticals via a sink is an important pathway into the environment (Bound and Voulvoulis 2005). The same opinion has been expressed in the case of selected antibiotics (Al-Maadheed et al. 2019).

In 1996, in the USA, $68 \%$ of people disposed of medicines down the toilet (Kuspis and Krenzelok 1996), and from 100 tested pharmacies, only $3 \%$ had a special protocol for expired medications (mostly returning to the producer). In 2007, the first federal guidelines were introduced which recommend the disposal of pharmaceuticals in household bins (Glassmeyer et al. 2009). In 2016, the primary route of drug disposal was household trash $(25 \%)$, while only $1 \%$ was disposed of down the toilet (Vatovec et al. 2017). In 2009, only 30 countries had a program for pharmaceutical disposal. Disposal practices differ around the world (Tong et al. 2011b). For example, in Ghana (2014), different disposal strategies were found among inhabitants-burying underground (38\%), waste bin (29\%), donation to friends $(21 \%)$, incineration (7\%), flushing down the toilet (4\%) and, finally, returning to the pharmacy (1\%) (Abruquah et al. 2014).

The returning program is of course the best practice. An analysis of pharmaceuticals returned to pharmacies can be found in the literature (Abahussain et al. 2012; Ibrahim et al. 2012). Furthermore, there are several informative campaigns on the disposal of pharmaceuticals and returning them to the pharmacy (for example http://medsdisposal.eu, http:// www.medicinewaste.com/campaign, http://www.returnmed. com.au). There are also national programs, like the National Return and Disposal of Unwanted Medicines (NatRUM) Project Audit (Bergen et al. 2013) in Australia and Voluntary Pharmaceutical Take-Back Programs in the Great Lake States (Product Stewardship Institute 2011). These campaigns have an impact on people's habits. Currently, less young people dispose of pharmaceuticals by flushing down the toilet (Vatovec et al. 2017). Thereby, there is a need for continuous increased awareness regarding the disposal of unused and expired pharmaceuticals. Users are generally willing to participate in such returning programs, even if they should pay the cost of disposal (Kotchen et al. 2009). Medicines returned to the pharmacies are disposed of mostly by incineration, including the packaging, because they are treated as hazardous waste (Kadam et al. 2016).

\section{Surface runoff and stormwater}

The pollution of surface runoff by pharmaceuticals is related with various activities: the use of solid sludge from WWTP for soil amendments, the use of reclaimed wastewater for soil irrigation, the use of slurry and liquid manure as fertilizers, and urination and defecation of grazing animals and pets (Li 2014; Bastos et al. 2020). A minor source is the use of antibiotics for the treatment of plant disease.

The use of pharmaceuticals for the treatment of pets is connected with discharge directly into the environment. The estimation (load) of this source has never been presented and is hard to calculate; some may say that this is a minor part of the total mass of pharmaceuticals introduced into the environment. The exact number of pets, especially cats and dogs, which are treated for tumors and cancer is unknown because there is no database nor registration requirement. More pets are treated daily because of the greater care, detection of disease and wealth of the owners. An increase in the sales of over-the-counter medication has been observed (Ramirez et al. 2015). The treatment of pets is often carried out in an experimental way, while the diagnostics of animal diseases is not so advanced as in the case of humans. In most cases, the same medicines are used both for humans and pets. Better control of pet medicines and reporting is needed for an 
estimation of the problem and a proposition of an optimal solution.

The antibiotics used for plant disease control are mainly streptomycin, oxytetracycline, gentamicin and oxalinic acid (McManus et al. 2002). They are used mostly to treat fire blight on valuable plants, but also on fruit, vegetables and tobacco plantations. The annual amount used worldwide is unknown. In the USA, less than $0.5 \%$ of antibiotics are used for plant treatment. Bacterial diseases of plants are very difficult to manage (McManus and Stockwell 2000). The general possibility of minimizing this pharmaceutical source is to keep the plant in a good condition and minimize the spread of the pathogen. Furthermore, some biological treatment, like beneficial fungi application, can be used for prevention (Robert et al. 2016). For example, fungi from the Trichoderma family can produce multiple enzymes, volatile metabolites such as 6-n-pentyl-2H-pyran-2-one, and a number of antibiotics, for example, trichodermin, trichodermol, gliovirin, gliotoxin, viridin, herzianolide, pyrones, peptaibols, ethylene and formic aldehyde (Ghorbanpour et al. 2018). The Bacillus species is interesting because of the fact that $8 \%$ of the total genome is devoted to the biosynthesis of secondary metabolites which have a broad spectrum of antagonistic activity against plant pathogenic bacteria, fungi and viruses (Fira et al. 2018). Lactobacillus plantarum strains were proven to have inhibited pathogen populations on plant surfaces as well (Daranas et al. 2019). Furthermore, plant growth-promoting fungi, plant probiotics and endophytic bacteria can also minimize the use of antibiotics (Hyakumachi 2016).

Stormwater is a cause of concern in urban areas, rather than rural areas. This is due to the fact that urban areas are more polluted by a cocktail of anthropogenic emissions (Markiewicz et al. 2017). Stormwater propagates pollution, also by pharmaceuticals (for example, carbamazepine (Osenbrück et al. 2007) and non-steroidal anti-inflammatory drugs (NSAIDs) (Caban et al. 2015)), to the groundwater used for drinking water. Of course, the presence of pharmaceuticals in stormwater is not caused by their presence in air and natural dust (there is currently no evidence of their presence in these matrices), but by runoff, illegal dumping of wastewater and unsealed systems, and overflow in combined sewer systems (Launay et al. 2016). For example, in New Orleans (U.S.), naproxen ( $<$ MDL-145 ng/l), ibuprofen ( $<$ MDL$674 \mathrm{ng} / \mathrm{L})$ and triclosan $(<\mathrm{MDL}-29 \mathrm{ng} / \mathrm{L})$ were found in stormwater canals (Boyd et al. 2004). Domestic markers, such as antibiotics, NSAIDs and trimethoprim, were found in stormwater in China (Yin et al. 2019).

The use of untreated solid sludge from WWTPs in particular causes a significant load of pharmaceuticals (hundreds of kilograms yearly) (Ivanová et al. 2018). Sludge is actually a cocktail of different chemicals with an anthropogenic character, such as microplastics (Pittura et al. 2018), brominated flame retardants (Demirtepe and Imamoglu 2019), phthalates, chlorinated paraffins, siloxanes, quaternary ammonium compounds, perfluorinated compounds and nanoparticles (Zhang et al. 2017). Sludge can be used treated or untreated, and a regulation limit is specified normally only for the heavy metal content. The disposal of sludge is about $50 \%$ of the WWTP operation cost; thereby, it is valuable to use it elsewhere as feedstock (Capodaglio and Callegari 2018). About $40 \%$ of the sludge produced in the EU (60 million tons per year) is used for agricultural application. The rest is used for compost production, landfill disposal and energy valorization. What is promising is that there is concern about the increasing production of sludge, and ways to reduce this problem are researched (Zhang et al. 2017).

Treated wastewater can be used as a valuable source of water. Reclaimed water is used mostly for agricultural soil irrigation, landscape irrigation (parks, golf courses), groundwater recharge, industrial use (for example, mining, power sector, manufacturing of paper), seawater intrusion barriers and potable water. The use of reclaimed wastewater for the irrigation of agricultural soil is the option more frequently used because of the general lack of availability of fresh water. Irrigation with treated wastewater has both pros and cons. The main advantages are the recycling of water and nutrients. The negative side is the introduction of contaminants which can inhibit the growth of plants, for example, the increase in sodicity (Erel et al. 2019). The use of reclaimed water contributes to the presence of antibiotic resistant bacteria and genes in the environment (Christou et al. 2017), together with other bacteria and viruses (Pepper and Gerba 2018; Girones et al. 2019). The use of such water also has an impact on the soil fungi community, which is known to perform important functions in a variety of natural processes, and for plant growing (Rangel et al. 2018). On the other hand, there are reports of the absence of negative effects of reclaimed water on the bacteria community, with positive effects on plant vegetation in a long irrigation time (Li et al. 2019a). However, the application of reclaimed water is strictly connected with the presence of pharmaceuticals in soil (Biel-Maeso et al. 2018).

One idea is to prohibit the use of reclaimed water during the winter, when soil organisms have minimal activity. Furthermore, proper safeguards should be established in order to avoid the consequences of the unintended entry of antibiotics into the field of agricultural via irrigation by reclaimed wastewater (Kuppusamy et al. 2018). The perfect solution is to purify the water before irrigation to lower the pharmaceutical content below the risk concentration. It needs to be mentioned that reclaimed water is also used for potable water and bottled water (Zhang et al. 2015; Ellis et al. 2019), and pollutants other than pharmaceuticals can be found in plants growing in irrigated soils (Liao et al. 2018); thereby, 
the advanced treatment of reclaimed water would be directly beneficial for human health.

A review of the treatment technology for reclaimed water, with a critical discussion, can be found in the literature $(\mathrm{Xu}$ et al. 2016). Generally, such techniques are applicable as: biological nitrification, denitrification, ammonia stripping, ionic exchange, biological phosphorus removal, coagulation, sedimentation and filtering, ultrafiltration, reverse osmosis, electrodialysis, distillation and cooling, ozonation, chlorination, activated carbon adsorption and biochemical treatment, microfiltration, air flotation (Xu et al. 2016). An interesting idea is to use reclaimed water in closed technological systems or as a cooling medium in the power sector (Cherchi et al. 2019).

The control of stormwater pollution can be performed only by knowing the dynamics of stormwater transport (Vezzaro et al. 2014). The traditional technologies of stormwater treatment are mechanical (screens, sieves, separators, filters), physicochemical (flotation, flocculation, sedimentation) and biological (ponds, wetlands, sand filters), and reduction by infiltration, storage and usage. Cheap materials and methods have already been proposed for stormwater treatment from hydrophobic pollutants (Björklund and Li 2015; Soleimanifar et al. 2016), while pharmaceuticals would probably need more advanced technology. The runoff from streets, rich in organics (plasticizers, polycyclic aromatic hydrocarbons, petroleum) and metals (Flanagan et al. 2018, 2019), can be treated by biofilters, such as bioswales. Biofilters are a good solution for nitrogen and phosphorus removal with little effort (Zhou et al. 2016). There are other green infrastructure practices already used around cities (Kazak et al. 2018; $\mathrm{Li}$ et al. 2019b). The efficiency of such systems in order to eliminate pharmaceuticals is unknown, but can be related to constructed wetlands. While reed is not the only option for constructed wetlands (more than 150 plants are already used (Kazak et al. 2018), some of them with an attractive appearance), this can be used in the future for the treatment of trace levels of pharmaceuticals from stormwater.

\section{Treatment of waters by advanced techniques}

There are several techniques for the reduction in micropollutants from a stream of wastewater. This review does not intend to compare them, but rather to present the options and specialist literature. The advantages and disadvantages of several available techniques (wastewater treatment plants (WWTPs) with activated sludge treatment, WWTPs with coagulation, constructed wetlands, chlorination, membrane bioreactors, micro-, ultra- and nanofiltration, reverse osmosis, ozonation, photocatalysis, advanced oxidation processes (AOPs, for example, photocatalysis, Fenton and photo-Fenton), adsorption and activated powder) have recently been presented by Patel et al. (Patel et al. 2019) according to the elimination of pharmaceuticals (in terms of efficiency, toxicity of products, cost, technical operation, among others). The current reviews devoted to techniques for the reduction in pharmaceuticals from wastewaters are obtained (Shi et al. 2017; Tiwari et al. 2017; Stadlmair et al. 2018; de Oliveira et al. 2020; Femina Carolin et al. 2020; Shah and Shah 2020). What should be stressed is that there is a need for a standardization of the criteria of evaluation of advanced techniques, because the report lacks important information (Fischer et al. 2019).

\section{Industrial wastewater}

Industrial sources include manufacturers of pharmaceuticals and cosmetics who use medications in the content of products. The impact of such sources can be presented by the concentrations of pharmaceuticals found in wastewater and finally, reservoirs. As an example, in one factory in China, the concentrations of oxytetracycline and oxalic acid were as high as $600 \mathrm{mg} / \mathrm{L}$ and $9100 \mathrm{mg} / \mathrm{L}$ in wastewaters, which were $10^{6}$ higher than the respective concentrations normally found in surface water. $20 \mathrm{~km}$ down the river, the concentration of the same antibiotics was $250 \mu \mathrm{g} / \mathrm{L}$, still higher than the medium concentration found in treated municipal wastewater. More examples can be found in the review (Cardoso et al. 2014), where the reported concentrations of pharmaceuticals were at the levels of $\mu \mathrm{g} / \mathrm{L}$ to $\mathrm{mg} / \mathrm{L}$. These data undeniably show the need for such wastewater treatment in the place of origin. In the USA, the wastewater from pharmaceutical manufacturing facilities was found to substantially increase the concentration of selected pharmaceuticals in municipal wastewater (Scott et al. 2018). Real case studies proved the effect of industrial discharge on fish, amphibians and the bacteria community (presented in the review (Cardoso et al. 2014)). A probabilistic approach has been proposed to assess the risk of pharmaceutical wastewater discharge (Cardoso et al. 2014).

Pharmaceutical wastewater types are differentiated in terms of chemical composition (Shi et al. 2017). Pharmaceutical manufacturing includes the following categories of actions: fermentation, extraction, chemical synthesis, formulation and packaging. Fermentation and chemical synthesis, in particular, produce hard-to-treat wastewater because of high $\mathrm{pH}$, salinity, the presence of organic solvent and the high load of carbon, organic solvents, heavy metals and ammonia (Zhao et al. 2019). The distribution of pharmaceuticals in pharmaceutical wastewater can be described to be rather stable as the manufacturers mostly focus on single/ several products at one time. One characteristic of pharmaceutical wastewater is actually the recommendation to use end-of-pipe technology-the stability of the matrix makes the treatment easy to optimize; the higher concentration of 
the pollutant makes the treatment more cost-effective (Mantovani et al. 2017; Kümmerer 2018). Thereby, industrial wastewater rich in pharmaceuticals should undergo special treatment at the place of origin before discharge into the environment or municipal WWTPs.

One solution is anaerobic treatment in traditional WWTPs, but the elimination of antibiotics should be obtained by advanced techniques (Shi et al. 2017). It was found that the bacteria community in pharmaceutical WWTPs differs from that in traditional WWTPs (Zhao et al. 2019). Generally, the presence of contaminants in high concentrations, especially antibacterial agents, inhibits the activated sludge; thereby, this technology is used less often. Instead, small reactors, often with membranes, are applied (Zhao et al. 2019). The applied technology should also eliminate the other chemicals used in the synthesis, such as heavy metals and organic solvents. The techniques of pharmaceutical wastewater treatment (Fenton, electro-Fenton, ozonation, biodegradation, sonochemical techniques, among others) are presented in the reviews (Tran et al. 2015a; Prabakar et al. 2018; Akhil et al. 2021). An example of a plant for the removal of pharmaceuticals in an industrial district in China can be found in the literature (Ma et al. 2016). A batch mode of treatment is often needed because of the complexity of the matrix of pharmaceutical wastewater.

Presently, the monitoring of industrial wastewater is focused on basic parameters, such as COD, BOD and heavy metal concentrations, as there are no legal limits of pharmaceuticals. In such cases, the impact of the discharge can be measured by biological factors, for example, the differences in biodiversity upstream and downstream of the discharge. Such a solution was used to assess the impact of industrial discharge on fish in France (an endocrine-disrupting effect was observed) (Sanchez et al. 2011). The general rule of prevention and "Best Available Technique" needs to be implemented for the reduction in such point sources of pharmaceuticals in the environment (Cardoso et al. 2014). Regular monitoring will bring an argument for decision-makers to enforce an improvement in the quality of treated wastewater among pharmaceutical manufacturing companies. Furthermore, the introduction of closed water systems into factories can bring even more environmental benefits.

\section{Hospital wastewater}

Hospitals (and also old people's homes, hospices and other health-care facilities) are another source of wastewater with a high content of pharmaceuticals. Most hospitals are connected to public sewage systems. Nevertheless, before entering the public system, this wastewater needs special care because of the high content of pathogens. In the review of Carraro et al. (Carraro et al. 2016), the characteristics of hospital effluents as well as a risk assessment are presented.
Generally, hospital effluents vary in characteristics, because several types of activities can take place in a hospital (routine patient care (laundries and kitchens) and highly specific operations like laboratories, hemodialysis and dental departments or radiotherapy). Chemical, biological and physical/ radioactive risks are all connected with hospital discharge. The above-mentioned review presents a comparison of pharmaceutical concentrations in hospital effluents, industrial effluents and domestic wastewater reported in the literature (2010-2014). The highest concentration of almost all target compounds, especially antibiotics, was observed in hospital wastewater (Wang et al. 2018). The contribution of hospital wastewater in the load of pharmaceuticals in municipal wastewater is stated to be significant by some researchers (Santos et al. 2013; Azuma et al. 2019). On the other hand, some authors claim that the volume of hospital wastewater is low and is a minor contribution to municipal wastewater (Kümmerer 2009; Cruz-Morató et al. 2014), or surface water (Xiang et al. 2018). What is indisputable is that there are classes of pharmaceuticals which were detected in higher concentrations in hospital wastewater, like those used only in hospitals (Le Corre et al. 2012) (for example, antipsychotic pharmaceuticals (Reichert et al. 2019)). Furthermore, antibiotic resistance genes can enter the environment together with hospital wastewater (Azuma et al. 2019).

The guidelines for liquid and solid wastes produced by hospitals are different around the world (Carraro et al. 2016). In Europe, there is no specific directive for the management of hospital wastewater. Nevertheless, member states have their own regulations. Generally, the direct disposal of hospital wastewater into surface water should be prohibited. Treatment and disposal into the surface water or pretreatment and disposal into WWTPs is recommended. The WHO recommendation can be found in the book entitled "Safe Management of Wastes from Health-care Activities" (2nd edition, 2014, Geneva) (Yves Chartier et al. 2014).

The waste treatment technology which can be used by health-care facilities is divided into thermal processes, chemical processes, irradiation technologies, biological processes and mechanical processes (Yves Chartier et al. 2014). The choice depends on the current waste characteristics. Several innovative technologies for the removal of pharmaceuticals from hospital wastewater have been presented during the last five years (Table 2). It needs to be mentioned that the vast majority of reports present pilotscale systems or laboratory-scale tests. The research also lacks a comparison of the efficiency and cost of tested systems, and the reduction in bacteria and viruses in a treated stream was not investigated. In one paper, the simultaneous reduction in antibiotics together with antibiotic resistance genes by advanced technology (membrane bioreactor treatment (MBR), ozonation, granulated activated carbon (GAC) and UV treatment) was presented in a real case study (Paulus 


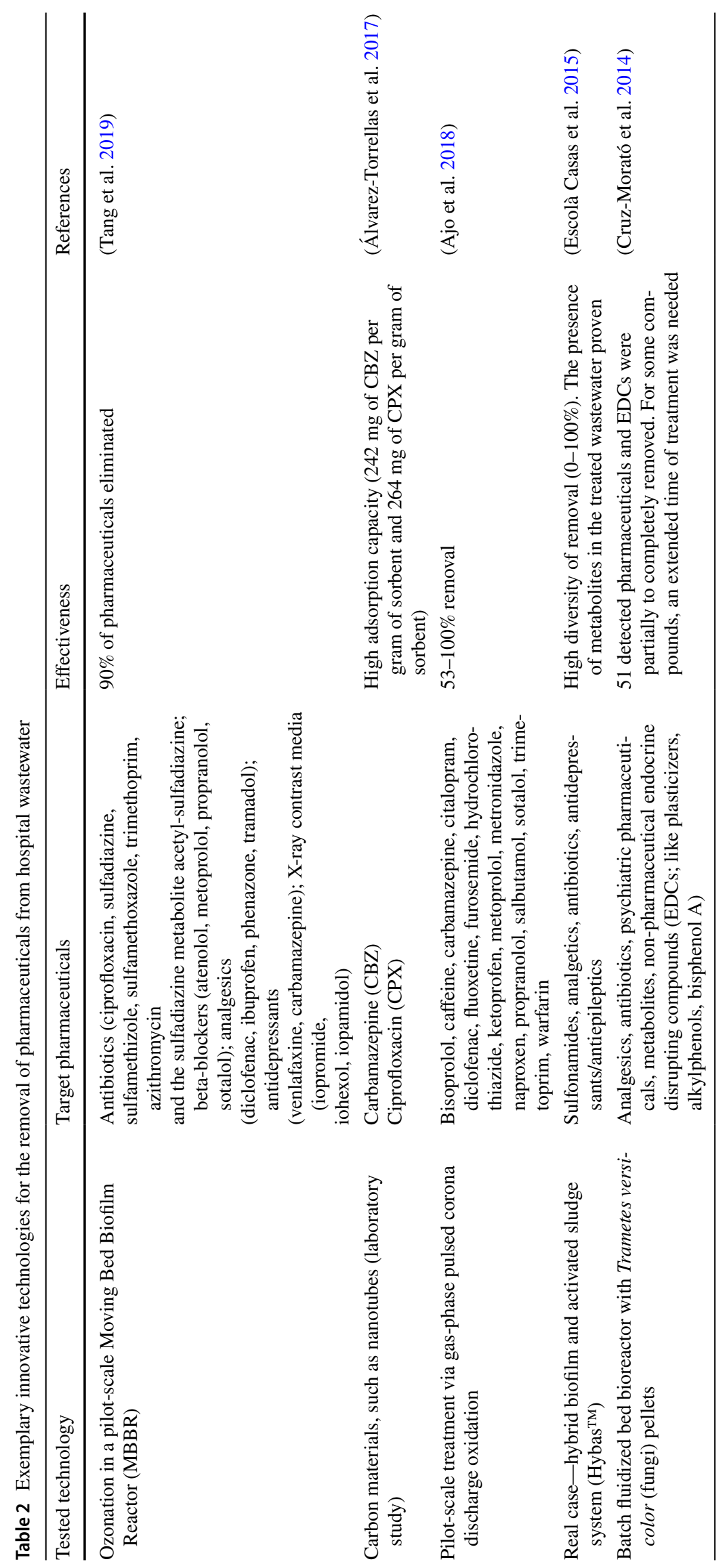


et al. 2019). What is promising is that a fungal reactor was capable of removing diclofenac (recalcitrant in municipal WWTPs) (Cruz-Morató et al. 2014).

Finally, advanced technologies should be applied for hospital wastewater, and regulations are highly needed in this area. The advantages of this can be the fact that often the chemical risk of the presence of pharmaceuticals is lowered by the application of advanced processes, together with the biological and radioactive risk of hospital wastewater. For anticancer pharmaceuticals, special care should be taken, as they are highly toxic (Białk-Bielińska et al. 2017). The individual management (collection, treatment) of human excretion from oncological patients was proposed as a solution (Ferrando-Climent et al. 2014).

\section{Wastewater from livestock}

Livestock production is connected with a high consumption of pharmaceuticals, mostly antibiotics. Antibiotics are used in India and China as growth promoters, while in the EU such a solution was banned in 2006. The contribution of China to global animal breeding is essential, as well as to the use of antibiotics in such production (Zhi et al. 2018). Nevertheless, all animal breeding is connected with a high concentration of antibiotics in wastewater, because these compounds do not fully metabolize, and the active conjugates are present in feces and urine. The concentrations of antibiotics (tetracyclines, macrolides and others) are reported at the level of a dozen $\mu \mathrm{g} / \mathrm{L}$ (Zhi et al. 2018; Gros et al. 2019). Other classes of pharmaceuticals, for example, antihelminthics and NSAIDs, can also be detected in slurry and manure (Łukaszewicz et al. 2016; Gros et al. 2019; Petrie and Camacho-Muñoz 2020). A direct toxic effect from this level of concentration is unlikely, but a change in the bacteria community was observed after a continuous flow of livestock wastewater (Jia et al. 2017). Reviews of the use/fate/environmental effects of veterinary antibiotics are presented in the literature (Kumar et al. 2005; Kuppusamy et al. 2018). The re-inspection of antibiotics shows that each group of antibiotics has different behavior, effects and risk to the agricultural environment (Eukaszewicz et al. 2016).

The treatment of such wastewater depends on its further use or disposal. Agricultural use is the most popular because of the high fertilization potential of this wastewater type (Gros et al. 2019). Anaerobic stabilization is the minimal treatment required before disposal in soil. Currently, more countries are banning the use of antibiotics which are important for human treatment and for livestock use. Existing gaps in the knowledge, recommendations and possible strategies to limit the presence of veterinary antibiotics in the agro-environment are presented in the review by Kuppusamy et al. (Kuppusamy et al. 2018). A review of antibiotic bioremediation has already been published (Kumar et al.
2019). A review of technologies for the elimination of antibiotics and hormones from swine wastewater can be found in the literature (Cheng et al. 2018). The proposed/needed urgent activities recommended by Kuppusamy et al., with the authors' own contribution, are presented in Table 3. The implementation of each of them would prevent the health risk of pharmaceuticals both to wildlife and humans by a potential reduction in the presence of antibiotic resistance.

\section{Aquaculture}

Aquaculture is the sector of industry where the production of plants or animals is placed inside water, namely in freshwater aquaculture $(63 \%)$, estuarine systems $(8 \%)$ or seawater systems (mariculture) (29\%) (Ottinger et al. 2016). The systems are rice fields, ponds (natural or artificial), cages and pens, raceways, tanks and recirculating systems, and each of them employs different ways to deal with waste (Dauda et al. 2018). Aquaculture is a booming industry in the world and China is the largest producer and exporter of aquatic products (Liu et al. 2017).

Several types of pharmaceuticals are used in aquaculture-antibiotics (in predominance), anti-parasitics, hormones and stimulants. Except stimulants injected directly into entrails, the pharmaceuticals are administered with food. This poses a risk of the water environment near the aquaculture. Some of the applied dose is dissolved with the water directly, while the rest is absorbed by fish or shrimps. Not all doses are absorbed inside the ingestion system, and return to the water. Furthermore, there are antibiotics which are not metabolized by fish and eliminated with urine to water. The example is oxytetracycline, which is the most popular antibiotic used in aquaculture (Zhang and Li 2007). Discharge from aquaculture was a primary source of the presence of antibiotics in Bohai Bay, China (Zou et al. 2011). Concentrations of sulfadiazine, amoxicillin, norfloxacin, ofloxacin and erythromycin in a pond of fish and shrimps ranged from 65 to $7722 \mathrm{ng} / \mathrm{L}$. In some Polish rivers, the concentration of fluoroquinolones was as high as $136 \mathrm{ng} / \mathrm{L}$ thanks to their use in the aquaculture of rainbow trout (Wagil et al. 2014, 2015). Despite pharmaceutical residues and bacteria resistance, aquaculture has an impact on landscapes, habitat destruction, erosion, diseases of natural organisms and food chain pollution. An overview of the current state and impact, and possibilities in the sustainable management of aquaculture, and future perspectives in relation to the warming effect can be found in the literature (Ottinger et al. 2016).

The low effectiveness of antibiotics used in aquaculture is caused by the fact that the fish which are already infected have no appetite and a significant amount of food with medication goes directly into the water. If a circulated system is used in aquaculture, the exchanged water enters the river without purification. Because of the fact that only a small 
Table 3 Proposed actions recommended by Kuppusamy et al. (2018) and us for the minimalization in antibiotics and antibiotic resistance in the environment, focusing on livestock production

\begin{tabular}{|c|c|}
\hline Category & Activity \\
\hline Lowering the use of pharmaceuticals in livestock & $\begin{array}{l}\text { The verification of the use of antibiotics, and elimination of those for which resistance is } \\
\text { already presented } \\
\text { A change in the diet of the human population, lowering the consumption of animal products } \\
\text { The identification of alternatives to the use of antibiotics (for example, herbal materials) } \\
\text { The development of improved nutritional programs to maintain good animal health and } \\
\text { thereby reduce the usage of antibiotics } \\
\text { The optimization or control of the use of antibiotics as feed additives } \\
\text { The development of standards of limits of antibiotic concentrations in organic fertilizers and } \\
\text { plant produce } \\
\text { Similarly to the use of pharmaceuticals in human medicine- the improvement in pharmaceu- } \\
\text { tical absorption }\end{array}$ \\
\hline $\begin{array}{l}\text { The elimination of pharmaceuticals from } \\
\text { obtained wastewater }\end{array}$ & $\begin{array}{l}\text { The development of new and/or the improvement in the efficiency of currently existing live- } \\
\text { stock manure pre-treatment technologies } \\
\text { Biological treatment and the containment of antibiotic resistance genes in manure } \\
\text { The setting-up of an on-farm methanogenic biogas system which could be a novel and energy- } \\
\text { efficient manure management approach on animal farms } \\
\text { The development of easily degradable pharmaceuticals }\end{array}$ \\
\hline Removal from soils & $\begin{array}{l}\text { Rhizosphere growth promoters as support for soil bioremediation } \\
\text { Bio-remediation by plants or fungi } \\
\text { Soil chemical remediation for places with high pollution }\end{array}$ \\
\hline $\begin{array}{l}\text { Increase in knowledge } \\
\text { and control programs }\end{array}$ & $\begin{array}{l}\text { Extensive studies on the fates (mixed antibiotics, interaction effects with other contaminants) } \\
\text { and ecological risks of antibiotics in agro-ecosystems } \\
\text { Conducting interdisciplinary research (microbiologists, organic- and geochemists, risk assess- } \\
\text { ment and industry scientists, environmental and agricultural engineers) } \\
\text { Monitoring programs and more frequent internal and external controls of animal feed, waste- } \\
\text { water and products }\end{array}$ \\
\hline
\end{tabular}

dose of applied pharmaceuticals reaches the injured tissue, the mass of medication needs to be enhanced. For example, a typical tetracycline dosage for the whole treatment of fish is $800 \mathrm{mg} / \mathrm{kg}$, six times more than that for terrestrial animals (European Medicine Agency 2014). In China, the dosage of antibiotics reaches $2.5 \mathrm{~g}$ of antibiotics per $\mathrm{kg}$ of feed (Liu et al. 2017). The duration of the antibiotic treatment depends on the disease and can reach 10 days. Nevertheless, it should be noted that, since 1981, sales of antibiotics used in aquaculture in Europe have declined by $99 \%$, while during the same period, the production of farmed fish increased more than 100-fold (European Medicine Agency 2014). On the other hand, the use of antibiotics in aquaculture in China is increasing, and banned antibiotics are still in use, and detectable in fresh and salt water (Liu et al. 2017).

The use of antibiotics in fish production causes a problem for the environment because of direct contact with water organisms and bacteria resistance to the antibiotics already mentioned (reviewed in (Santos and Ramos 2018)). The emergency increase in bacteria resistance in aquaculture means that alternative environmentally friendly approaches are urgently needed (Pérez-Sánchez et al. 2018). Although the minimalization of fish diseases is one of the most important tasks, there are ways to reduce the use of antibiotics in aquaculture. A reduction in the amount of fish inside one tank causes less stress for fish and improves their resistance. Guidelines for the responsible use of antibiotics are also available (Serrano 2005). Vaccinations are present, but have limitations, especially in the case of crustacea. Other approaches are the use of bacteriophages, microbiota, phytobiotics, postbiotics, prebiotics, probiotics and synbiotics (reviewed in (Pérez-Sánchez et al. 2018), with specifications of both the advantages and limitations of each approach). The use of probiotics (bacteria from the family of Actinobacteria, Bacteroidetes, Firmicutes, Proteobacteria and yeast) is in its initial stages in China (Wang et al. 2019).

Holistic regulations in this industry are also urgently needed. In Norway, the use of antibiotics in salmon farms is the lowest around the world, thanks to special regulations (Olaussen 2018). Unfortunately, at the same time, the consumption of chemicals for sea lice treatment has increased several times because of the increase in numbers of this parasite in farming-dense regions, both in naturally and artificially produced salmon stock (a similar problem occurs with Early Mortality Syndrome in shrimps (Sanguanrut et al. 
2018)). What is worrying is that the resistance of sea lice to these chemicals starts to be observed both in natural and artificial fish stock (salmon and trout) (Fjørtoft et al. 2017). One solution is the collation of a new aquaculture in a diseasefree region, which has been applied in Scotland to manage the sea lice infection of salmon (Murray and Gubbins 2016).

In the case of recirculating aquaculture systems, wastewater can be treated by bioremediation, and traditional and advanced technology before discharge into natural water, similar to other types of wastewaters. The exemplary technologies tested or implemented for aquaculture are presented in Table 4, and more can be found recent reviews (He et al. 2016; Santos and Ramos 2018; Jasmin et al. 2020). A review of the management of pharmaceutical pollution in aquaculture in China, as the region with most intensive aquaculture production, can be found in the literature ( $\mathrm{He}$ et al. 2016). The other issue is the quality of water which is used in aquaculture, as in some water reservoirs there are pollutants such as endocrine disruptors, which can affect the fish population (Ismail et al. 2017), or pesticides and antibiotics affecting shrimps (Butcherine et al. 2018; Saxena et al. 2018). Thereby, the idea of using closed systems or applying ground water has already been highlighted (Little et al. 2018).

What should be mentioned is that disinfectants and antifoulants are other chemicals which are applied in aquaculture, and, together with nutrients, are waste which should be dealt with so as not to disturb the surrounding environment (Dauda et al. 2018). Furthermore, by-products and intermediates should be considered during the technology testing step, due to the confirmation of their presence in several studies (Kanakaraju et al. 2018).

\section{Landfills}

The leachates of municipal landfills are sources of a cocktail of chemicals, such as new emerging pollutants (a list of some of them can be found in Eggen et al. 2010; Qi et al.
2018)). Medicines disposed of in the garbage and in bins are distributed to landfills mostly in the packaging in which they were supplied. A study performed in the USA showed that the mean concentration of pharmaceuticals in solid municipal waste is $8.1 \mathrm{mg} / \mathrm{kg}$ (Musson and Townsend 2009). During this storage, the packaging can become opened, and the active compound, if still present, can leak with rain water to the landfill depth (Musson and Townsend 2009). Exemplary pharmaceuticals and their concentrations are presented in the reports, and their concentration levels are similar to raw and treated municipal wastewater (Clarke et al. 2015; Lu et al. 2016). Pollution of the groundwater caused by landfills has been reported (Samadder et al. 2017; Branchet et al. 2019). The detected concentrations of some pharmaceuticals are so high that they have created a real risk of the quality of groundwater (Peng et al. 2014). What is alarming is that antibiotics and antibiotic resistance genes are also detected in such leachates (Chung et al. 2018; You et al. 2018; Zhao et al. 2018).

There are possibilities for the treatment of such wastewater (as described in Bolyard and Reinhart 2016; Bakraouy et al. 2017)), and in terms of standard regulated parameters they are effective. This exemplary treatment includes mixing with municipal wastewater, recycling, anaerobic and aerobic systems, coagulation/flocculation and sorption on carbon materials (Costa et al. 2019). There are technologies for groundwater treatment by advanced processes (Qi et al. 2018; Li et al. 2019c), but they are expensive and rarely used for pharmaceuticals, or can have low efficiency (Lu et al. 2016). There is an idea to implement treatment by constructed wetlands, but the efficiency of the removal of pharmaceuticals is not total for each compound (Yi et al. 2017). On the one hand, with more restrictive regulations and higher numbers of new landfills with good groundwater protection technology, the leachates from wastewater will be reduced. On the other, the already existing landfills will have more leakage because of the aging of geo-membranes, and such aging increases the risk of the deterioration of

Table 4 The exemplary technologies for the treatment of aquaculture wastewater

\begin{tabular}{|c|c|c|c|}
\hline Type of aquaculture & Applied technology of treatment & Effect & References \\
\hline $\begin{array}{l}\text { Recirculating aquaculture systems } \\
\text { (RAS), 10-20\% daily water } \\
\text { removal, American eels }\end{array}$ & $\mathrm{UV}$ and $\mathrm{UV} / \mathrm{H}_{2} \mathrm{O}_{2}$ & $\begin{array}{l}\text { Natural removal of estrogens to the } \\
\text { detection limits }\end{array}$ & (Bennett et al. 2018) \\
\hline $\begin{array}{l}\text { Flow-through } \\
\text { System-laboratory scale }\end{array}$ & ZVI-activated persulfate & $\begin{array}{l}\text { Removal of } 68 \% \text { of sulfadimethoxine } \\
\text { from filtered and } 74 \% \text { from unfil- } \\
\text { tered discharge water }\end{array}$ & (Chokejaroenrat et al. 2019) \\
\hline $\begin{array}{l}\text { Groundwater in a tank with an effec- } \\
\text { tive volume and hydraulic retention } \\
\text { time of } 200 \mathrm{~L} \text { and } 17.7 \mathrm{~min} \text {, } \\
\text { Plecoglossus altivelis fish }\end{array}$ & $\begin{array}{l}\text { Adsorption and photo-degradation } \\
\text { on zeolite/ } / \mathrm{TiO}_{2} \text { composites }\end{array}$ & $\begin{array}{l}\text { Total decomposition of sulfamono- } \\
\text { methoxine }\end{array}$ & (Nomura et al. 2017) \\
\hline $\begin{array}{l}\text { Through-flow system, laboratory } \\
\text { study }\end{array}$ & $\begin{array}{l}\text { Constructed wetland (Phragmites } \\
\text { australis) }\end{array}$ & $\begin{array}{l}>87 \% \text { removal of antibiotics and } \\
\text { other micropollutants }\end{array}$ & (Gorito et al. 2018) \\
\hline
\end{tabular}


groundwater quality, and creates a problem for the future (Xu et al. 2018). Thereby, the most effective action is the prevention of the disposal of pharmaceuticals to landfills.

\section{Wastewater treatment plants}

The presence of pharmaceuticals in municipal wastewater may be attributed to several factors. First of all, the application of pharmaceuticals via oral, inhalation or epidermal routes and their incomplete metabolism in the human body results in a discharge into household wastewater. The rate of metabolism of pharmaceuticals depends on their type, the method of application and the patient (age, condition, applied dose, etc.), and ranges from 0 to $100 \%$. The metabolism of pharmaceuticals is not equivalent to their degradation. In some cases, the native compound is only converted into polar conjugates to be easily removed by urine. Dermatological medicines are applied in high excess, and the active compound is not totally transmitted through the skin. Therefore, they are flushed into wastewater without a metabolic pathway. Due to the large population, household wastewater can be treated as a dispersive, continuous source. The concentration of a single compound from one house may be below the detection limit. Nevertheless, bearing in mind that a certain percentage of the population takes medicines every day, human daily life is one of the most important sources of pharmaceuticals in wastewater. Up to 2020, 350 000 chemicals and mixtures of chemicals have been registered for production and use (Wang et al. 2020); thereby, a mixture of pharmaceuticals together with other pollutants is present in the wastewater, with an unrecognized toxic potential (Sigurnjak Bureš et al. 2021).

Generally, lipophilic compounds are more easily eliminated in WWTPs compared to hydrophilic compounds because of the sorption process on activated sludge. Nevertheless, the polar fraction of wastewater should be eliminated as well, as it has a toxic and eco-toxic potential (Hrubik et al. 2016). There are plenty of new technologies for treatment, presented in the literature, focused on pharmaceutical elimination (Patel et al. 2019). Some of them aim to eliminate both antibiotics and antibiotic resistance genes (for example, by membrane bioreactor systems (Le et al. 2018)). What is evident is that most new technologies were tested on the lab scale or pilot scale. The exemplary technologies used for pharmaceutical removal from wastewater streams can be found in the reviews (Ahmed et al. 2015; Jung et al. 2015; Zepon Tarpani and Azapagic 2018; Kümmerer et al.

Table 5 General problems with the implementation of new technologies in wastewater treatment plants (WWTPs), based on (Kümmerer 2009; Zepon Tarpani and Azapagic 2018; Kümmerer et al. 2019), with own comments and impressions

\begin{tabular}{ll}
\hline Concern & Needed actions and possible solutions \\
\hline $\begin{array}{c}\text { Effectiveness can differ from compound to compound, and tests are } \\
\text { performed for a limited number of pharmaceuticals. While pharma- }\end{array}$ & $\begin{array}{c}\text { Before the implementation of new technologies, advanced research } \\
\text { needs to be performed, aimed at verifying the co-elimination of }\end{array}$ \\
$\begin{array}{l}\text { ceuticals can enter the environment in various forms (Kümmerer } \\
\text { organic carbon, trace contaminants of broad chemical characteristics, } \\
\text { nutics; the question is if the new technologies will be effective for } \\
\text { each representative. There is no technology which can eliminate all }\end{array}$ & $\begin{array}{l}\text { ucts need to be evaluated. The deconjugation of metabolic products } \\
\text { also needs to be evaluated. A sequential treatment can be applied }\end{array}$
\end{tabular}

compounds

The presence of degradation products is often not tested; however, some of them can have a higher toxic effect compared to native pharmaceuticals (Majumder et al. 2019)

The number of new chemicals, not only pharmaceuticals, is increasing; thereby, today's new technologies could be ineffective toward compounds of the future

The increase in the cost would be significant, as well as the energy cost (together with the increase in greenhouse gases) (Jones et al. 2007). From the technological point of view-a longer retention time will bring a high operational cost with low benefits

Resistance genes could be retained on bio-reactors

New technologies need to have a flexibility toward modification and development

WWTPs could have their own power source (for example, bio-gas from fermentation); the reclaimed water and treated sludge can be valuable products on the market. The environmental benefits can be calculated in money terms, and WWTPs can be subsidized more by public money

Currently, no data have been obtained to prove this. There is a need for advanced research. Methods to reduce the propagation of resistance genes in wastewaters have been developed (Pazda et al. 2019)

Low-income countries could have a long time span for the introduction International funding and cooperation is needed in this field. New of new technologies technologies need to be optimized with regard to operation costs, and ideally-to be self-sufficient

The ecotoxicity potential generated by the treatments themselves being higher than the ecotoxicity potential of the pharmaceuticals being treated

The adaptation of processes to needs, choosing from many available. Green approaches are also available (Azimi and Pendashteh 2016) 
2019); thereby, we have not presented all the technologies in this review.

There are general doubts among experts about the use of new technologies for the treatment of wastewaters (Table 5). One of the main concerns is the cost of the implementation of new technologies. A critical analysis of the cost of two advanced systems: 1 . sand filters + ozone + granulated activated carbon, and 2 . sand filters + membrane filtration + reverse osmosis, is presented in (Jones et al. 2007). This analysis shows that the total cost of a new system is economically and environmentally undesirable, because of the high energy consumption and $\mathrm{CO}_{2}$ emissions. What was highlighted is that an already existing solution, like the coupling of nitrification + de-nitrification + biological phosphorus removal, can be a great possibility for the removal of endocrine disruptors and pharmaceuticals (with an annotation that the presence of transformation products was not investigated). In summary, the author questioned the use of advanced treatment techniques. A similar point of view was presented in another study (Wenzel et al. 2008). An analysis of the life cycle of advanced wastewater treatment techniques for the removal of pharmaceuticals also shows that often the use of advanced treatment techniques is not recommended, because of the production of the toxicity of the product and the negative impact on climate (Zepon Tarpani and Azapagic 2018). These are general disadvantages of downstream actions-increased cost and the presence of by-products. Nevertheless, the only a slight cost increase is expected, if integrated the removal of micropollutants in a long-term strategy (Eggen et al. 2014). Despite high cost of new technology implementation and operation, in UE several countries are initiate this process (EurEau 2019). For example, the Switzerland has begun in 2016 implementing plan on investing in improvements to cut the release of micropollutants to the aquatic environment from its sewage treatment plants using ozonation process in 100 of 700 existing Swiss WWTPs (Bourgin et al. 2018).

End-of-pipe solutions (namely-the reduction in the concentration of contaminants in the place where they are produced) seem to be encouraged in the case of pharmaceuticals (Kümmerer 2018). Nevertheless, advanced treatment processes are not compatible with sustainable development because they focus on end-of-pipe solutions linked to the abovementioned problems of the presence of transformation products (Leder et al. 2015). Bearing in mind that even if advanced treatment techniques were implemented, some content of pharmaceuticals would finally end up in surface, ground and drinking water, a better solution is to work on the "beginning of the pipe." The results clearly show the advantage of prevention at the input and integrated emission management compared to the implementation of advanced treatment techniques for micropollutants generally (Kümmerer et al. 2019).

\section{Accidental and intentional introduction of untreated} wastewater

The last source, which is immeasurable and has not been estimated so far, is the intentional or accidental introduction of untreated wastewater. The Combined Sewer System Overflow is a source of substantial anthropogenic pollution (Dittmer et al. 2020), such as frequently found pharmaceuticals (Kay et al. 2017). While the overflow frequency is hard to predict, the untreated wastewater in such systems is introduced to the natural water receiver intentionally. Furthermore, accidents and damage to WWTP systems also occur. For example, in August 2019, in Warsaw, the sewage collector of the WWTP malfunctioned, and over 3.6 million $\mathrm{m}^{3}$ of untreated wastewaters was introduced directly into the Vistula River (Stepnowski et al. 2020). In this streams of wastewater, several pharmaceuticals were detected in concentrations of dozen $\mu \mathrm{g} / \mathrm{L}$. Furthermore, there are still undeclared installations and intended leaks in installations. In low-income countries, the lack of wastewater treatment causes as high a concentration of pharmaceuticals in rivers as in untreated wastewater in high-income countries (for example, carbamazepine, selected antibiotics and NSAIDs ranged up to $1900 \mathrm{ng} / \mathrm{L}$ in the Ahar River in India (Williams et al. 2019)). Until today, no accidents have been reported in the manufacturing of pharmaceuticals causing a catastrophe in the natural environment. Ways to avoid this source of pollution include primary the investment in the modernization of the sewage system, connecting all houses to sewage systems, and monitoring and connecting the stormwater sewage system to the municipal sewage system. Furthermore, there is need for looking for illegal dumps of wastewater, external controls in pharmaceutical plants, and the improvement in permit systems.

\section{Actions prioritization}

The prioritization of actions would be helpful for problem management, but it is hard to perform. Some insights presented in 2006 give an expert analysis of critical points in the management of the pharmaceutical problem (DoerrMacEwen and Haight 2006). Group of 27 experts from university, government and industry fields were asked in interviews (open-ended and closed-ended questions) for their opinions concerning the effectiveness and feasibility of several actions: advanced treatment, educating medical professionals to reduce prescription rates, pharmaceuticalreturn programs, requiring all municipalities to have secondary or better WWTPs, separate treatment of hospital wastewater, optimization of existing WWTPs, incentives 
for the manufacturing of green pharmaceuticals, and risk assessment regulations. Concerning effectiveness, advanced treatment was the best option (the highest ranking score), but at the same time, the experts had the opinion that this would be hard to implement. The only low score was noted for "incentives for green drug manufacturing." After several year of research, it seems to be necessary to repeat this prioritization.

Figure 2 summarizes the types of action presented in this review in the form of a pyramid of needs. Exemplary actions were referred to. The pyramid was used in order show which action gives long-term effects with benefits both for humans and the environment (lower-lying boxes). The structure of this pyramid can be adjusted to specific pharmaceuticals. As highlighted, it is possible to work before the pharmaceutical life cycle starts-by increasing the health status/ wellness of humans (working in the downstream of health) and the quality of the environment (here, also combating climate change should be added). The actions preventing the diseases, such as healthy lifestyle and early diagnosis, have measurable benefits for society and lower the cost of healthcare (Chung et al. 2020; de Boer et al. 2020; Laroche et al. 2020). The cost of actions is hard to determine, as well as the environmental profits, but generally, working in the downstream of the life cycle is connected with higher costs. In previous sections, the actions of mitigation were presented, mostly related to "hard" management. What is lacking, and is intuitive, is the need for education and information. The actions proposed in this review do not guarantee a solution to the problem in a short period, and the effects will not be easy to observe. Nevertheless, the good example of lowering the phenazone level in the groundwater in Germany, thanks to the preventative action taken, can be a motivation (Reddersen and Heberer 2002). The specific group of pharmaceuticals needed subjective treatment, and the minimalization action needs to be adjusted to current local conditions. The starting point should be modeling of the loads and transport dynamic to estimate the main sources and hotspots of pollution, starting with global scale (Vermeulen et al. 2019), following regions (Björlenius et al. 2018) to specific catchment (Vezzaro et al. 2014).

As was mentioned in introduction, the primary action should be to increase human and animal wellness, as the base of the pyramid of needs presented in Fig. 2. It is highlighted by experts in different fields that working upstream of the pharmaceutical life cycle and the benign-by-design concept are desired in both veterinary and human medicine. Several actions in this stage are connected with benefits for humans, as they increase safety in the use of medication. Advanced treatment technologies, a solution with short-term effects, should be implemented whenever other options are impossible.

\section{Conclusions}

In summary, this review presents an impressive number of actions in different fields of pharmaceuticals life cycles. One of the bargaining chips to take action is the argument that the minimalization of the level of pharmaceuticals in the

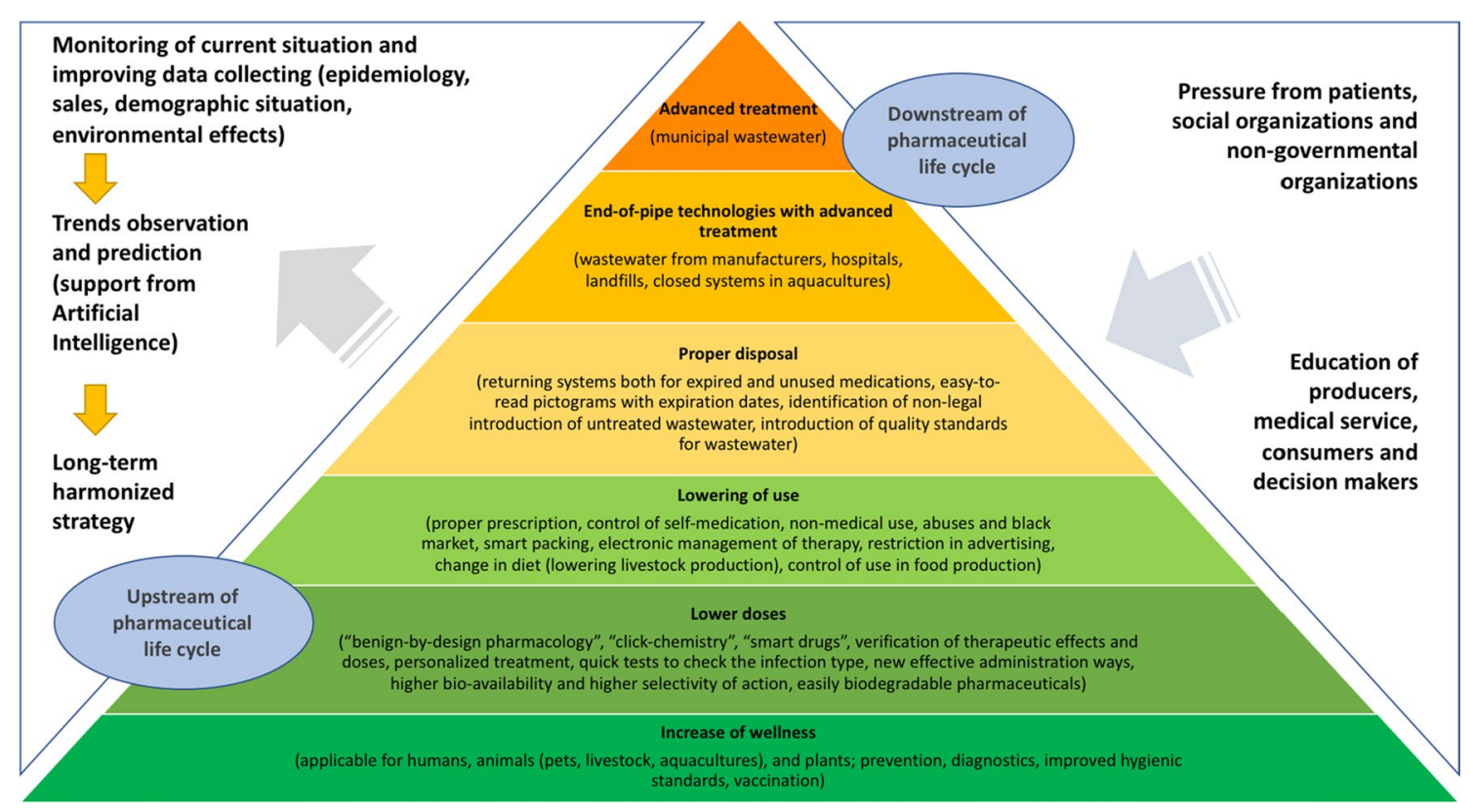

Fig. 2 Pyramid of needs presenting actions which can be performed to minimize the presence of pharmaceuticals in the environment, with benefits for human wellness 
environment will benefit human life. Namely, it will increase the safety of pharmaceutical use, lower the cost of pharmaceuticals, lower the number of interactions between pharmaceuticals and allergy syndromes, increase the efficiency of treatment and lower the level of pharmaceutical residues in food. The logical consequence of the equality for humans and the environment of the effect of actions is connected with mutually inseparable dependencies within the concept of environmental health (Daughton 2003; Daughton and Ruhoy 2011). Working on the upstream of the pharmaceutical life cycle will reduce the impact not only from the native compounds, but also from the metabolites and transformation products created during advanced treatment.

This wide range of actions for the minimalization of pharmaceuticals should be taken in parallel by various players, globally and at different organization levels: scientific institutions, governments, non-governmental organizations, manufacturers, industry and households. Optimistically, after the literature review of 1990-2018, it is visible that there are rising concerns regarding the pharmaceutical contamination of the environment, as well as efforts of remediation (Patel et al. 2019).

Acknowledgements Financial support was provided by the National Science Center under grants UMO- 2015/17/D/ST4/00774 and UMO-2019/35/B/NZ9/00253.

Open Access This article is licensed under a Creative Commons Attribution 4.0 International License, which permits use, sharing, adaptation, distribution and reproduction in any medium or format, as long as you give appropriate credit to the original author(s) and the source, provide a link to the Creative Commons licence, and indicate if changes were made. The images or other third party material in this article are included in the article's Creative Commons licence, unless indicated otherwise in a credit line to the material. If material is not included in the article's Creative Commons licence and your intended use is not permitted by statutory regulation or exceeds the permitted use, you will need to obtain permission directly from the copyright holder. To view a copy of this licence, visit http://creativecommons.org/licenses/by/4.0/.

\section{References}

Abahussain E, Waheedi M, Koshy S (2012) Practice, awareness and opinion of pharmacists toward disposal of unwanted medications in Kuwait. Saudi Pharm J 20:195-201. https://doi.org/10.1016/j. jsps.2012.04.001

Abruquah AA, Drewry JA, Taylor F (2014) What happens to unused, expired and unwanted medications? A survey of a community-based medication disposal practices. Int J Dev Sustain 3:2175-2185

Ahmed MB, Zhou JL, Ngo HH, Guo W (2015) Adsorptive removal of antibiotics from water and wastewater: progress and challenges. Sci Total Environ 532:112-126. https://doi.org/10.1016/j.scito tenv.2015.05.130

Ajo P, Preis S, Vornamo T et al (2018) Hospital wastewater treatment with pilot-scale pulsed corona discharge for removal of pharmaceutical residues. J Environ Chem Eng 6:1569-1577. https://doi.org/10.1016/j.jece.2018.02.007

Akhil D, Lakshmi D, Senthil Kumar P et al (2021) Occurrence and removal of antibiotics from industrial wastewater. Environ Chem Lett. https://doi.org/10.1007/s10311-020-01152-0

Akici A, Aydin V, Kiroglu A (2018) Assessment of the association between drug disposal practices and drug use and storage behaviors. Saudi Pharm J 26:7-13. https://doi.org/10.1016/j.jsps.2017. 11.006

Alhanout K, Bun SS, Retornaz K et al (2017) Prescription errors related to the use of computerized provider order-entry system for pediatric patients. Int J Med Inform 103:15-19. https://doi. org/10.1016/j.ijmedinf.2017.04.005

Al-Maadheed S, Goktepe I, Latiff ABA, Shomar B (2019) Antibiotics in hospital effluent and domestic wastewater treatment plants in Doha, Qatar. J Water Process Eng 28:60-68. https://doi.org/10. 1016/j.jwpe.2019.01.005

Almuzaini T, Choonara I, Sammons H (2013) Substandard and counterfeit medicines: a systematic review of the literature. BMJ Open 3:1-7. https://doi.org/10.1136/bmjopen-2013-002923

Álvarez-Torrellas S, Peres JA, Gil-Álvarez V et al (2017) Effective adsorption of non-biodegradable pharmaceuticals from hospital wastewater with different carbon materials. Chem Eng J 320:319-329. https://doi.org/10.1016/j.cej.2017.03.077

aus der Beek T, Weber FA, Bergmann A et al (2016) Pharmaceuticals in the environment-global occurrences and perspectives. Environ Toxicol Chem 35:823-835. https://doi.org/10.1002/ etc. 3339

Azimi SC, Pendashteh A (2016) Green technologies for wastewater treatment. In: Second International Conference in New Research on chemistry and chemical engineering

Azuma T, Otomo K, Kunitou M et al (2019) Environmental fate of pharmaceutical compounds and antimicrobial-resistant bacteria in hospital effluents, and contributions to pollutant loads in the surface waters in Japan. Sci Total Environ 657:476-484. https://doi.org/10.1016/j.scitotenv.2018.11.433

Bagnis S, Fitzsimons MF, Snape J et al (2018) Processes of distribution of pharmaceuticals in surface freshwaters: implications for risk assessment. Environ Chem Lett 16:1193-1216. https://doi. org/10.1007/s10311-018-0742-7

Bakraouy H, Souabi S, Digua K et al (2017) Optimization of the treatment of an anaerobic pretreated landfill leachate by a coagulation-flocculation process using experimental design methodology. Process Saf Environ Prot 109:621-630. https:// doi.org/10.1016/j.psep.2017.04.017

Balk A, Holzgrabe U, Meinel L (2015) Pro et contra' ionic liquid drugs-challenges and opportunities for pharmaceutical translation. Eur J Pharm Biopharm 94:291-304. https://doi.org/10. 1016/j.ejpb.2015.05.027

Bastos N, Ruivo CF, da Silva S, Melo SA (2018) Exosomes in cancer: use them or target them? Semin Cell Dev Biol 78:13-21. https://doi.org/10.1016/j.semcdb.2017.08.009

Bastos CM, Soubrand M, Le GT et al (2020) Occurrence, fate and environmental risk assessment of pharmaceutical compounds in soils amended with organic wastes. Geoderma 375:114498. https://doi.org/10.1016/j.geoderma.2020.114498

Begley E, Mcveigh J, Hope V et al (2017) Image and performance enhancing. Drugs 4:15-21

Bennett JL, Mackie AL, Park Y, Gagnon GA (2018) Advanced oxidation processes for treatment of $17 \beta$-Estradiol and its metabolites in aquaculture wastewater. Aquac Eng 83:40-46. https:// doi.org/10.1016/j.aquaeng.2018.08.003

Bergen P, Kong D, George J, et al (2013) The National Return and Disposal of Unwanted Medicines (NatRUM) project audit: Final report 
Białk-Bielińska A, Mulkiewicz E, Stokowski M et al (2017) Acute aquatic toxicity assessment of six anti-cancer drugs and one metabolite using biotest battery-biological effects and stability under test conditions. Chemosphere 189:689-698. https:// doi.org/10.1016/j.chemosphere.2017.08.174

Biel-Maeso M, Corada-Fernández C, Lara-Martín PA (2018) Monitoring the occurrence of pharmaceuticals in soils irrigated with reclaimed wastewater. Environ Pollut 235:312-321. https://doi. org/10.1016/j.envpol.2017.12.085

Björklund K, Li L (2015) Evaluation of low-cost materials for sorption of hydrophobic organic pollutants in stormwater. J Environ Manage 159:106-114. https://doi.org/10.1016/j.jenvman.2015. 05.005

Björlenius B, Ripszám M, Haglund P et al (2018) Pharmaceutical residues are widespread in Baltic sea coastal and offshore watersscreening for pharmaceuticals and modelling of environmental concentrations of carbamazepine. Sci Total Environ 633:14961509. https://doi.org/10.1016/j.scitotenv.2018.03.276

Bolyard SC, Reinhart DR (2016) Application of landfill treatment approaches for stabilization of municipal solid waste. Waste Manag 55:22-30. https://doi.org/10.1016/j.wasman.2016.01.024

Borgschulte M, Corredor-Waldron A, Marshall G (2018) A path out: prescription drug abuse, treatment, and suicide. J Econ Behav Organ 149:169-184. https://doi.org/10.1016/j.jebo.2018.03.006

Bound JP, Voulvoulis N (2005) Household disposal of pharmaceuticals as a pathway for aquatic contamination in the United Kingdom. Environ Health Perspect 113:1705-1711. https://doi.org/10. 1289/ehp. 8315

Bourgin M, Beck B, Boehler M et al (2018) Evaluation of a full-scale wastewater treatment plant upgraded with ozonation and biological post-treatments: abatement of micropollutants, formation of transformation products and oxidation by-products. Water Res 129:486-498. https://doi.org/10.1016/j.watres.2017.10.036

Boyd GR, Palmeri JM, Zhang S, Grimm DA (2004) Pharmaceuticals and personal care products (PPCPs) and endocrine disrupting chemicals (EDCs) in stormwater canals and Bayou St. John in New Orleans, Louisiana, USA. Sci Total Environ 333:137-148. https://doi.org/10.1016/j.scitotenv.2004.03.018

Branchet P, Ariza Castro N, Fenet H et al (2019) Anthropic impacts on Sub-Saharan urban water resources through their pharmaceutical contamination (Yaoundé, Center Region, Cameroon). Sci Total Environ 660:886-898. https://doi.org/10.1016/j.scito tenv.2018.12.256

Braund R, Peake BM, Shieffelbien L (2009) Disposal practices for unused medications in New Zealand. Environ Int 35:952-955. https://doi.org/10.1016/j.envint.2009.04.003

Bu Q, Shi X, Yu G et al (2016) Pay attention to non-wastewater emission pathways of pharmaceuticals into environments. Chemosphere 165:515-518. https://doi.org/10.1016/j.chemosphere.2016. 09.078

Bundschuh M, Filser J, Lüderwald S et al (2018) Nanoparticles in the environment: where do we come from, where do we go to? Environ Sci Eur. https://doi.org/10.1186/s12302-018-0132-6

Butcherine P, Benkendorff K, Kelaher B, Barkla BJ (2018) The risk of neonicotinoid exposure to shrimp aquaculture. Chemosphere 217:329-348. https://doi.org/10.1016/j.chemosphere.2018.10. 197

Caban M, Lis E, Kumirska J, Stepnowski P (2015) Determination of pharmaceutical residues in drinking water in Poland using a new SPE-GC-MS(SIM) method based on Speedisk extraction disks and DIMETRIS derivatization. Sci Total Environ 538:402-411. https://doi.org/10.1016/j.scitotenv.2015.08.076

Caldwell DJ, Mertens B, Kappler K et al (2016) A risk-based approach to managing active pharmaceutical ingredients in manufacturing effluent. Environ Toxicol Chem 35:813-822. https://doi.org/10. 1002/etc. 3163

Capodaglio AG, Callegari A (2018) Feedstock and process influence on biodiesel produced from waste sewage sludge. J Environ Manage 216:176-182. https://doi.org/10.1016/j.jenvman.2017.03.089

Cardoso O, Porcher JM, Sanchez W (2014) Factory-discharged pharmaceuticals could be a relevant source of aquatic environment contamination: review of evidence and need for knowledge. Chemosphere 115:20-30. https://doi.org/10.1016/j.chemosphere. 2014.02.004

Carli Lorenzini G, Mostaghel R, Hellström D (2018) Drivers of pharmaceutical packaging innovation: a customer-supplier relationship case study. J Bus Res 88:363-370. https://doi.org/10.1016/j. jbusres.2017.11.030

Carr T (2017) Too Many Meds? America's Love Affair With Prescription Medication. In: https://www.consumerreports.org/prescripti on-drugs/too-many-meds-americas-love-affair-with-prescripti on-medication/

Carraro E, Bonetta SS, Bertino C et al (2016) Hospital effluents management: chemical, physical, microbiological risks and legislation in different countries. J Environ Manage 168:185-199. https://doi.org/10.1016/j.jenvman.2015.11.021

Cavicchioli R, Ripple WJ, Timmis KN et al (2019) Scientists' warning to humanity: microorganisms and climate change. Nat Rev Microbiol 17:569-586. https://doi.org/10.1038/ s41579-019-0222-5

Cenci C (2016) Narrative medicine and the personalisation of treatment for elderly patients. Eur J Intern Med 32:22-25. https://doi.org/ 10.1016/j.ejim.2016.05.003

Chartier Y, Emmanuel J, Pieper U et al (2014) Safe management of wastes from health-care activities, 2nd edn. World Health Organization, Geneva

Cheng DL, Ngo HH, Guo WS et al (2018) Bioprocessing for elimination antibiotics and hormones from swine wastewater. Sci Total Environ 621:1664-1682. https://doi.org/10.1016/j.scitotenv. 2017.10.059

Cherchi C, Kesaano M, Badruzzaman M et al (2019) Municipal reclaimed water for multi-purpose applications in the power sector: a review. J Environ Manage 236:561-570. https://doi.org/10. 1016/j.jenvman.2018.10.102

Chokejaroenrat C, Sakulthaew C, Angkaew A et al (2019) Remediating sulfadimethoxine-contaminated aquaculture wastewater using ZVI-activated persulfate in a flow-through system. Aquac Eng 84:99-105. https://doi.org/10.1016/j.aquaeng.2018.12.004

Christou A, Agüera A, Bayona JMM et al (2017) The potential implications of reclaimed wastewater reuse for irrigation on the agricultural environment: the knowns and unknowns of the fate of antibiotics and antibiotic resistant bacteria and resistance genes-a review. Water Res 123:448-467. https://doi.org/10.1016/j.watres. 2017.07.004

Chung S, Brooks BWW (2019) Identifying household pharmaceutical waste characteristics and population behaviors in one of the most densely populated global cities. Resour Conserv Recycl 140:267-277. https://doi.org/10.1016/j.resconrec.2018.09.024

Chung SS, Zheng JS, Burket SR, Brooks BW (2018) Select antibiotics in leachate from closed and active landfills exceed thresholds for antibiotic resistance development. Environ Int 115:89-96. https:// doi.org/10.1016/j.envint.2018.03.014

Chung CCY, Leung GKC, Mak CCY et al (2020) Rapid whole-exome sequencing facilitates precision medicine in paediatric rare disease patients and reduces healthcare costs. Lancet Reg HealWest Pacific 1:100001. https://doi.org/10.1016/j.lanwpc.2020. 100001

Clarke BO, Anumol T, Barlaz M, Snyder SA (2015) Investigating landfill leachate as a source of trace organic pollutants. Chemosphere 
127:269-275. https://doi.org/10.1016/j.chemosphere.2015.02. 030

Coopman V, Cordonnier J (2012) Counterfeit drugs and pharmaceutical preparations seized from the black market among bodybuilders. Ann Toxicol Anal 24:73-80. https://doi.org/10.1051/ata/2012012

Costa AM, de Souza Marotta RG, Alfaia CJC (2019) Landfill leachate treatment in Brazil—an overview. J Environ Manage 232:110 116. https://doi.org/10.1016/j.jenvman.2018.11.006

Costa-Font J, Gemmill Toyama M (2011) Does cost sharing really reduce inappropriate prescriptions among the elderly? Health Policy (New York) 101:195-208. https://doi.org/10.1016/j.healt hpol.2010.09.001

Cree IA (2013) Designing personalised cancer treatments. J Control Release 172:405-409. https://doi.org/10.1016/j.jconrel.2013.07. 007

Cruz-Morató C, Lucas D, Llorca M et al (2014) Hospital wastewater treatment by fungal bioreactor: removal efficiency for pharmaceuticals and endocrine disruptor compounds. Sci Total Environ 493:365-376. https://doi.org/10.1016/j.scitotenv.2014.05.117

Cutica I, Mc Vie G, Pravettoni G (2014) Personalised medicine: the cognitive side of patients. Eur J Intern Med 25:685-688. https:// doi.org/10.1016/j.ejim.2014.07.002

Czaplewski L, Bax R, Clokie M et al (2016) Alternatives to antibioticsa pipeline portfolio review. Lancet Infect Dis 16:239-251. https:// doi.org/10.1016/S1473-3099(15)00466-1

da Justa Neves DB, Caldas ED (2017) GC-MS quantitative analysis of black market pharmaceutical products containing anabolic androgenic steroids seized by the Brazilian Federal Police. Forensic Sci Int 275:272-281. https://doi.org/10.1016/j.forsciint.2017.03. 016

Daranas N, Roselló G, Cabrefiga J et al (2019) Biological control of bacterial plant diseases with Lactobacillus plantarum strains selected for their broad-spectrum activity. Ann Appl Biol 174:92-105. https://doi.org/10.1111/aab.12476

Dauda AB, Ajadi A, Tola-Fabunmi AS, Akinwole AO (2018) Waste production in aquaculture: sources, components and managements in different culture systems. Aquac Fish. https://doi.org/ 10.1016/j.aaf.2018.10.002

Daughton CG (2003) Cradle-to-cradle stewardship of drugs for minimizing their environmental disposition while promoting human health. I. rational for and avenues toward a green pharmacy. Environ Health Perspect 111:757-774. https://doi.org/10.1289/ ehp.5947

Daughton CG (2014) The Matthew effect and widely prescribed pharmaceuticals lacking environmental monitoring: case study of an exposure-assessment vulnerability. Sci Total Environ 466467:315-325. https://doi.org/10.1016/j.scitotenv.2013.06.111

Daughton CG (2016) Pharmaceuticals and the environment (PiE): evolution and impact of the published literature revealed by bibliometric analysis. Sci Total Environ 562:391-426. https://doi.org/ 10.1016/j.scitotenv.2016.03.109

Daughton CG, Ruhoy IS (2011) Green pharmacy and pharmecovigilance: prescribing and the planet. Expert Rev Clin Pharmacol 4:211-232. https://doi.org/10.1586/ecp.11.6

de Boer WIJ, Dekker LH, Koning RH et al (2020) How are lifestyle factors associated with socioeconomic differences in health care costs? Evidence from full population data in the Netherlands. Prev Med (Baltim) 130:105929. https://doi.org/10.1016/j.ypmed. 2019.105929

de Oliveira M, Frihling BEF, Velasques J et al (2020) Pharmaceuticals residues and xenobiotics contaminants: occurrence, analytical techniques and sustainable alternatives for wastewater treatment. Sci Total Environ 705:135568. https://doi.org/10.1016/j.scito tenv.2019.135568

Demirtepe H, Imamoglu I (2019) Levels of polybrominated diphenyl ethers and hexabromocyclododecane in treatment plant sludge: implications on sludge management. Chemosphere 221:606-615. https://doi.org/10.1016/j.chemosphere.2019.01.060

Deloitte Sustainability (2018) Options for a strategic approach to pharmaceuticals in the environment-Final Report

Dittmer U, Bachmann-Machnik A, Launay MA (2020) Impact of combined sewer systems on the quality of urban streams: frequency and duration of elevated micropollutant concentrations. Water (Switzerland). https://doi.org/10.3390/w12030850

Doerr-MacEwen NA, Haight ME (2006) Expert stakeholders' views on the management of human pharmaceuticals in the environment. Environ Manage 38:853-866. https://doi.org/10.1007/ s00267-005-0306-Z

Ebert I, Amato R, Arne H, Konradi S (2015) Pharmaceuticals in the environment - avoidance, reduction and monitoring

Eggen T, Moeder M, Arukwe A (2010) Municipal landfill leachates: a significant source for new and emerging pollutants. Sci Total Environ 408:5147-5157. https://doi.org/10.1016/j.scitotenv. 2010.07.049

Eggen RIL, Hollender J, Joss A et al (2014) Reducing the discharge of micropollutants in the aquatic environment: the benefits of upgrading wastewater treatment plants. Environ Sci Technol 48:7683-7689. https://doi.org/10.1021/es500907n

Egorova KS, Ananikov VP (2018) Fundamental importance of ionic interactions in the liquid phase: a review of recent studies of ionic liquids in biomedical and pharmaceutical applications. J Mol Liq 272:271-300. https://doi.org/10.1016/j.molliq.2018.09.025

Ekakoro JE, Okafor CC (2018) Antimicrobial use practices of veterinary clinicians at a veterinary teaching hospital in the United States. Vet Anim Sci 7:100038. https://doi.org/10.1016/j.vas. 2018.09.002

Ellis SF, Savchenko OM, Messer KD (2019) What's in a name? Branding reclaimed water. Environ Res 172:384-393. https://doi.org/ 10.1016/j.envres.2019.01.059

Erel R, Eppel A, Yermiyahu U et al (2019) Long-term irrigation with reclaimed wastewater: implications on nutrient management, soil chemistry and olive (Olea europaea L.) performance. Agric Water Manag 213:324-335. https://doi.org/10.1016/j.agwat. 2018.10.033

Escolà Casas M, Chhetri RKK, Ooi G et al (2015) Biodegradation of pharmaceuticals in hospital wastewater by a hybrid biofilm and activated sludge system (Hybas). Sci Total Environ 530 531:383-392. https://doi.org/10.1016/j.scitotenv.2015.05.099

EurEau (2019) Treating micropollutants at waste water treatment plants

Femina Carolin C, Senthil Kumar P, Janet Joshiba G, Vinoth Kumar V (2020) Analysis and removal of pharmaceutical residues from wastewater using membrane bioreactors: a review. Environ Chem Lett. https://doi.org/10.1007/s10311-020-01068-9

Ferrando-Climent L, Rodriguez-Mozaz S, Barceló D (2014) Incidence of anticancer drugs in an aquatic urban system: from hospital effluents through urban wastewater to natural environment. Environ Pollut 193:216-223. https://doi.org/10.1016/j.envpol.2014. 07.002

Fira D, Dimkić I, Berić T et al (2018) Biological control of plant pathogens by Bacillus species. J Biotechnol 285:44-55. https://doi.org/ 10.1016/j.jbiotec.2018.07.044

Fischer A, van Wezel AP, Hollender J et al (2019) Development and application of relevance and reliability criteria for water treatment removal efficiencies of chemicals of emerging concern. Water Res 161:274-287. https://doi.org/10.1016/j.watres.2019. 05.088

Fjørtoft HB, Besnier F, Stene A et al (2017) The Phe362Tyr mutation conveying resistance to organophosphates occurs in high frequencies in salmon lice collected from wild salmon and trout. Sci Rep 7:1-10. https://doi.org/10.1038/s41598-017-14681-6

Flanagan K, Branchu P, Boudahmane L et al (2018) Field performance of two biofiltration systems treating micropollutants from road 
runoff. Water Res 145:562-578. https://doi.org/10.1016/j.watres. 2018.08.064

Flanagan K, Branchu P, Boudahmane L et al (2019) Retention and transport processes of particulate and dissolved micropollutants in stormwater biofilters treating road runoff. Sci Total Environ 656:1178-1190. https://doi.org/10.1016/j.scitotenv.2018.11.304

Flower R (2004) Lifestyle drugs: pharmacology and the social agenda. Trends Pharmacol Sci 25:182-185. https://doi.org/10.1016/j.tips. 2004.02.006

Ghorbanpour M, Omidvari M, Abbaszadeh-Dahaji P et al (2018) Mechanisms underlying the protective effects of beneficial fungi against plant diseases. Biol Control 117:147-157. https://doi.org/ 10.1016/j.biocontrol.2017.11.006

Girones R, Gonzales-Gustavson E, Calvo M et al (2019) Quantitative risk assessment of norovirus and adenovirus for the use of reclaimed water to irrigate lettuce in Catalonia. Water Res 153:91-99. https://doi.org/10.1016/j.watres.2018.12.070

Glassmeyer ST, Hinchey EK, Boehme SE et al (2009) Disposal practices for unwanted residential medications in the United States. Environ Int 35:566-572. https://doi.org/10.1016/j.envint.2008. 10.007

Goh CF, Lane ME (2014) Formulation of diclofenac for dermal delivery. Int J Pharm 473:607-616. https://doi.org/10.1016/j.ijpharm. 2014.07.052

Gorito AM, Ribeiro AR, Gomes CR et al (2018) Constructed wetland microcosms for the removal of organic micropollutants from freshwater aquaculture effluents. Sci Total Environ 644:11711180. https://doi.org/10.1016/j.scitotenv.2018.06.371

Gros M, Mas-Pla J, Boy-Roura M et al (2019) Veterinary pharmaceuticals and antibiotics in manure and slurry and their fate in amended agricultural soils: findings from an experimental field site (Baix Empordà, NE Catalonia). Sci Total Environ 654:13371349. https://doi.org/10.1016/j.scitotenv.2018.11.061

He Z, Cheng X, Kyzas GZ, Fu J (2016) Pharmaceuticals pollution of aquaculture and its management in China. J Mol Liq 223:781789. https://doi.org/10.1016/j.molliq.2016.09.005

Hignite C, Azarnoff DL (1977) Drugs and drug metabolites as environmental contaminants: chlorophenoxyisobutyrate and salicylic acid in sewage water effluent. Life Sci 20:337-341

Hossen S, Hossain MK, Basher MK et al (2018) Smart nanocarrierbased drug delivery systems for cancer therapy and toxicity studies: a review. J Adv Res. https://doi.org/10.1016/j.jare.2018.06. 005

Hrubik J, Glisic B, Tubic A et al (2016) Toxicological and chemical investigation of untreated municipal wastewater: fraction- and species-specific toxicity. Ecotoxicol Environ Saf 127:153-162. https://doi.org/10.1016/j.ecoenv.2016.01.018

Hulme S, Bright D, Nielsen S (2018) The source and diversion of pharmaceutical drugs for non-medical use: a systematic review and meta-analysis. Drug Alcohol Depend 186:242-256. https:// doi.org/10.1016/j.drugalcdep.2018.02.010

Hyakumachi M (2016) Research on biological control of plant diseases: present state and perspective. Jpn J Phytopathol 79:123-127. https://doi.org/10.3186/jjphytopath.79.123

Ibrahim SZ, Mamdouh HM, El-Haddad IZ (2012) Analysis of medications returned to community pharmacies in Alexandria. Egypt Life Sci J 9:746-751. https://doi.org/10.1345/aph.1M209

International Initiative on Water Quality-IIWQ (2017) Pharmaceuticals in the aquatic environment of the Baltic Sea region A status report

Ioannou F, Burnsteel C, Mackay DKJ, Gay CG (2018) Regulatory pathways to enable the licencing of alternatives to antibiotics. Biologicals 53:72-75. https://doi.org/10.1016/j.biologicals.2018. 03.003

Ismail NAH, Wee SY, Aris AZ (2017) Multi-class of endocrine disrupting compounds in aquaculture ecosystems and health impacts in exposed biota. Chemosphere 188:375-388. https://doi.org/10. 1016/j.chemosphere.2017.08.150

Ivanová L, Mackulak T, Grabic R et al (2018) Pharmaceuticals and illicit drugs - a new threat to the application of sewage sludge in agriculture. Sci Total Environ 634:606-615. https://doi.org/10. 1016/j.scitotenv.2018.04.001

Jamhour A, El-Kheir A, Salameh P et al (2017) Antibiotic knowledge and self-medication practices in a developing country: a crosssectional study. Am J Infect Control 45:384-388. https://doi.org/ 10.1016/j.ajic.2016.11.026

Jasmin MY, Syukri F, Kamarudin MS, Karim M (2020) Potential of bioremediation in treating aquaculture sludge: review article. Aquaculture 519:734905. https://doi.org/10.1016/j.aquaculture. 2019.734905

Jia S, Zhang XX, Miao Y et al (2017) Fate of antibiotic resistance genes and their associations with bacterial community in livestock breeding wastewater and its receiving river water. Water Res 124:259-268. https://doi.org/10.1016/j.watres.2017.07.061

Jones OAH, Green PG, Voulvoulis N, Lester JN (2007) Questioning the excessive use of advanced treatment to remove organic micropollutants from wastewater. Environ Sci Technol 41:5085-5089. https://doi.org/10.1021/es0628248

Jung C, Son A, Her N et al (2015) Journal of industrial and engineering chemistry removal of endocrine disrupting compounds, pharmaceuticals, and personal care products in water using carbon nanotubes: a review. J Ind Eng Chem 27:1-11. https:// doi.org/10.1016/j.jiec.2014.12.035

Kadam A, Patil S, Patil S, Tumkur A (2016) Pharmaceutical waste management an overview. Indian J Pharm Pract 9:2-8. https:// doi.org/10.5530/ijopp.9.1.2

Kanakaraju D, Glass BD, Oelgemöller M (2018) Advanced oxidation process-mediated removal of pharmaceuticals from water: a review. J Environ Manage 219:189-207. https://doi.org/10. 1016/j.jenvman.2018.04.103

Kay P, Hughes SR, Ault JR et al (2017) Widespread, routine occurrence of pharmaceuticals in sewage effluent, combined sewer overflows and receiving waters. Environ Pollut 220:14471455. https://doi.org/10.1016/j.envpol.2016.10.087

Kazak JK, Chruściński J, Szewrański S (2018) The development of a novel decision support system for the location of green infrastructure for stormwater management. Sustain 10:4388. https://doi.org/10.3390/su10124388

Kotchen M, Kallaos J, Wheeler K et al (2009) Pharmaceuticals in wastewater: behavior, preferences, and willingness to pay for a disposal program. J Environ Manage 90:1476-1482. https:// doi.org/10.1016/j.jenvman.2008.10.002

Kumar KC, Gupta S, Chander Y, Singh AK (2005) Antibiotic use in agriculture and its impact on the terrestrial environment. Adv Agron 87:1-54. https://doi.org/10.1016/S0065-2113(05) 87001-4

Kumar M, Jaiswal S, Sodhi KK et al (2019) Antibiotics bioremediation: perspectives on its ecotoxicity and resistance. Environ Int 124:448-461. https://doi.org/10.1016/j.envint.2018.12.065

Kümmerer K (2008) Pharmaceuticals in the environment-a brief summary. In: Kümmerer K (ed) Pharmaceuticals in the environment sources fate effects and risks, third. Springer, Berlin, pp 3-21

Kümmerer K (2009) The presence of pharmaceuticals in the environment due to human use-present knowledge and future challenges. J Environ Manage 90:2354-2366. https://doi.org/10. 1016/j.jenvman.2009.01.023

Kümmerer K (2018) Chapter 12-Management of environmental contaminants from health care: sustainable pharmacy. In: Health care and environmental contamination, environmental contaminants, pp 225-237. https://www.sciencedirect.com/science/artic le/pii/B9780444638571000127?via\%3Dihub 
Kümmerer K, Dionysiou DD, Olsson O, Fatta-Kassinos D (2019) Reducing aquatic micropollutants-increasing the focus on input prevention and integrated emission management. Sci Total Environ 652:836-850. https://doi.org/10.1016/j.scitotenv.2018.10.219

Kuppusamy S, Kakarla D, Venkateswarlu K et al (2018) Veterinary antibiotics (VAs) contamination as a global agro-ecological issue: a critical view. Agric Ecosyst Environ 257:47-59. https:// doi.org/10.1016/j.agee.2018.01.026

Kuspis DA, Krenzelok E (1996) What happens to expired medications? A survey of community medication disposal. Vet Hum Toxicol 38:48-48

Laroche E, L'Espérance S, Mosconi E (2020) Use of social media platforms for promoting healthy employee lifestyles and occupational health and safety prevention: a systematic review. Saf Sci 131:104931. https://doi.org/10.1016/j.ssci.2020.104931

Launay MA, Dittmer U, Steinmetz H (2016) Organic micropollutants discharged by combined sewer overflows - characterisation of pollutant sources and stormwater-related processes. Water Res 104:82-92. https://doi.org/10.1016/j.watres.2016.07.068

Le Corre KS, Ort C, Kateley D et al (2012) Consumption-based approach for assessing the contribution of hospitals towards the load of pharmaceutical residues in municipal wastewater. Environ Int 45:99-111. https://doi.org/10.1016/j.envint.2012.03.008

Le T-H, Ng C, Tran NH et al (2018) Removal of antibiotic residues, antibiotic resistant bacteria and antibiotic resistance genes in municipal wastewater by membrane bioreactor systems. Water Res 145:498-508. https://doi.org/10.1016/j.watres.2018.08.060

Leder C, Rastogi T, Kümmerer K (2015) Putting benign by design into practice-novel concepts for green and sustainable pharmacy: designing green drug derivatives by non-targeted synthesis and screening for biodegradability. Sustain Chem Pharm 2:31-36. https://doi.org/10.1016/j.scp.2015.07.001

Li WC (2014) Occurrence, sources, and fate of pharmaceuticals in aquatic environment and soil. Environ Pollut 187:193-201. https://doi.org/10.1016/j.envpol.2014.01.015

Li Y (2020) Competing eco-labels and product market competition. Resour Energy Econ. https://doi.org/10.1016/j.reseneeco.2020. 101149

Li T, Cipolla D, Rades T, Boyd BJ (2018) Drug nanocrystallisation within liposomes. J Control Release 288:96-110. https://doi.org/ 10.1016/j.jconrel.2018.09.001

Li B, Cao Y, Guan X et al (2019a) Microbial assessments of soil with a 40-year history of reclaimed wastewater irrigation. Sci Total Environ 651:696-705. https://doi.org/10.1016/j.scitotenv.2018. 09.193

Li C, Peng C, Chiang PC et al (2019b) Mechanisms and applications of green infrastructure practices for stormwater control: a review. J Hydrol 568:626-637. https://doi.org/10.1016/j.jhydrol.2018. 10.074

Li L, Fu X, Ai J et al (2019c) Process parameters study and organic evolution of old landfill leachate treatment using photo-Fentonlike systems: $\mathrm{Cu} 2+$ vs $\mathrm{Fe} 2+$ as catalysts. Sep Purif Technol 211:972-982. https://doi.org/10.1016/j.seppur.2018.10.063

Liao R, Liu F, Wang J et al (2018) Migration and health risks of nonylphenol and bisphenol a in soil-winter wheat systems with long-term reclaimed water irrigation. Ecotoxicol Environ Saf 158:28-36. https://doi.org/10.1016/j.ecoenv.2018.03.082

Little DC, Young JA, Zhang W et al (2018) Sustainable intensification of aquaculture value chains between Asia and Europe: a framework for understanding impacts and challenges. Aquaculture 493:338-354. https://doi.org/10.1016/j.aquaculture.2017.12.033

Liu X, Steele JC, Meng XZ (2017) Usage, residue, and human health risk of antibiotics in Chinese aquaculture: a review. Environ Pollut 223:161-169. https://doi.org/10.1016/j.envpol.2017.01.003
Lu MC, Chen YY, Chiou MR et al (2016) Occurrence and treatment efficiency of pharmaceuticals in landfill leachates. Waste Manag 55:257-264. https://doi.org/10.1016/j.wasman.2016.03.029

Lu M, Zhao X, Xing H et al (2018) Comparison of exosome-mimicking liposomes with conventional liposomes for intracellular delivery of siRNA. Int J Pharm 550:100-113. https://doi.org/10.1016/j. ijpharm.2018.08.040

Łukaszewicz P, Maszkowska J, Mulkiewicz E et al (2016) Impact of veterinary pharmaceuticals on the agricultural environment: a re-inspection. Rev Environ Contam Toxicol. https://doi.org/10. $1007 / 398$

Łukaszewicz P, Białk-Bielińska A, Dołżonek J et al (2018) A new approach for the extraction of tetracyclines from soil matrices: application of the microwave-extraction technique. Anal Bioanal Chem 410:1697-1707. https://doi.org/10.1007/ s00216-017-0815-7

Lusetti M, Licata M, Silingardi E et al (2018) Appearance/image- and performance-enhancing drug users: a forensic approach. Am J Forensic Med Pathol 39:325-329. https://doi.org/10.1097/PAF. 0000000000000424

Ma K, Qin Z, Zhao Z et al (2016) Toxicity evaluation of wastewater collected at different treatment stages from a pharmaceutical industrial park wastewater treatment plant. Chemosphere 158:163-170. https://doi.org/10.1016/j.chemosphere.2016.05. 052

Majumder A, Gupta B, Gupta AK (2019) Pharmaceutically active compounds in aqueous environment: a status, toxicity and insights of remediation. Environ Res 176:108542. https://doi.org/10.1016/j. envres.2019.108542

Mantovani A, Tarola O, Vergari C (2017) End-of-pipe or cleaner production? How to go green in presence of income inequality and pro-environmental behavior. J Clean Prod 160:71-82. https://doi. org/10.1016/j.jclepro.2017.01.110

Markiewicz A, Björklund K, Eriksson E et al (2017) Emissions of organic pollutants from traffic and roads: priority pollutants selection and substance flow analysis. Sci Total Environ 580:1162-1174. https://doi.org/10.1016/j.scitotenv.2016.12.074

McManus P, Stockwell V (2000) Antibiotics for plant diseases control: silver bullets or rusty sabers. APSnet Featur Artic. https://doi. org/10.1094/apsnetfeature-2000-0600

McManus PS, Stockwell VO, Sundin GW, Jones AL (2002) Antibiotic use in plant agriculture. Annu Rev Phytopathol 40:443-465. https://doi.org/10.1146/annurev.phyto.40.120301.093927

Mehuys E, Crombez G, Paemeleire K et al (2019) Self-Medication with over-the-counter analgesics: a survey of patient characteristics and concerns about pain medication. J Pain 20:215-223. https:// doi.org/10.1016/j.jpain.2018.09.003

Mohan PL, Sharma AK, Panwar SS (2014) Identification and quantification of prescription errors. Med J Armed Forces India 70:149_ 153. https://doi.org/10.1016/j.mjafi.2014.01.002

Monteith S, Glenn T (2018) Searching online to buy commonly prescribed psychiatric drugs. Psychiatry Res 260:248-254. https:// doi.org/10.1016/j.psychres.2017.11.037

Münch S, Wohlrab J, Neubert RH (2017) Dermal and transdermal delivery of pharmaceutically relevant macromolecules. Eur J Pharm Biopharm 119:235-242. https://doi.org/10.1016/j.ejpb. 2017.06.019

Murray AG, Gubbins M (2016) Spatial management measures for disease mitigation as practiced in Scottish aquaculture. Mar Policy 70:93-100. https://doi.org/10.1016/j.marpol.2016.04.052

Musson SE, Townsend TG (2009) Pharmaceutical compound content of municipal solid waste. J Hazard Mater 162:730-735. https:// doi.org/10.1016/j.jhazmat.2008.05.089 
Nasseri B, Soleimani N, Rabiee N et al (2018) Point-of-care microfluidic devices for pathogen detection. Biosens Bioelectron 117:112-128. https://doi.org/10.1016/j.bios.2018.05.050

Ng AWY, Chan AHS, Ho VWS (2017) Comprehension by older people of medication information with or without supplementary pharmaceutical pictograms. Appl Ergon 58:167-175. https://doi.org/ 10.1016/j.apergo.2016.06.005

Nomura Y, Fukahori S, Fukada H, Fujiwara T (2017) Removal behaviors of sulfamonomethoxine and its degradation intermediates in fresh aquaculture wastewater using zeolite/TiO2 composites. J Hazard Mater 340:427-434. https://doi.org/10.1016/j.jhazmat. 2017.07.034

O'Connell PJ, Harms CT, Allen JRF (1998) Metolachlor, S-metolachlor and their role within sustainable weed management. Crop Prot 17:207-2012. https://doi.org/10.1016/S0261-2194(98)80011-2

OECD (2019) Pharmaceutical residues in freshwater: hazards and policy responses

Okamoto Y, Taguchi K, Sakuragi M et al (2018) In vivo drug delivery efficiency of albumin-encapsulated liposomes as hydrophobic drug carriers. J Drug Deliv Sci Technol 47:62-66. https://doi. org/10.1016/j.jddst.2018.07.001

Olaussen JO (2018) Environmental problems and regulation in the aquaculture industry. Insights Nor Mar Policy 98:158-163. https://doi.org/10.1016/j.marpol.2018.08.005

Omonijo FA, Ni L, Gong J et al (2018) Essential oils as alternatives to antibiotics in swine production. Anim Nutr 4:126-136. https:// doi.org/10.1016/j.aninu.2017.09.001

Osenbrück K, Gläser HR, Knöller K et al (2007) Sources and transport of selected organic micropollutants in urban groundwater underlying the city of Halle (Saale), Germany. Water Res 41:32593270. https://doi.org/10.1016/j.watres.2007.05.014

Ottinger M, Clauss K, Kuenzer C (2016) Aquaculture: relevance, distribution, impacts and spatial assessments - a review. Ocean Coast Manag 119:244-266. https://doi.org/10.1016/j.oceco aman.2015.10.015

Patel M, Kumar R, Kishor K et al (2019) Pharmaceuticals of emerging concern in aquatic systems: chemistry, occurrence, effects, and removal methods. Chem Rev 119:3510-3673. https://doi. org/10.1021/acs.chemrev.8b00299

Paulus GK, Hornstra LM, Alygizakis N et al (2019) The impact of on-site hospital wastewater treatment on the downstream communal wastewater system in terms of antibiotics and antibiotic resistance genes. Int J Hyg Environ Health. https://doi.org/10. 1016/j.ijheh.2019.01.004

Pazda M, Kumirska J, Stepnowski P, Mulkiewicz E (2019) Antibiotic resistance genes identified in wastewater treatment plant systems-a review. Sci Total Environ. https://doi.org/10.1016/j. scitotenv.2019.134023

Peng X, Ou W, Wang C et al (2014) Occurrence and ecological potential of pharmaceuticals and personal care products in groundwater and reservoirs in the vicinity of municipal landfills in China. Sci Total Environ 490:889-898. https://doi.org/ 10.1016/j.scitotenv.2014.05.068

Pepper IL, Gerba CP (2018) Risk of infection from Legionella associated with spray irrigation of reclaimed water. Water Res 139:101-107. https://doi.org/10.1016/j.watres.2018.04.001

Pérez-Sánchez T, Mora-Sánchez B, Balcázar JL (2018) Biological approaches for disease control in aquaculture: advantages, limitations and challenges. Trends Microbiol 26:896-903. https:// doi.org/10.1016/j.tim.2018.05.002

Petrie B, Camacho-Muñoz D (2020) Analysis, fate and toxicity of chiral non-steroidal anti-inflammatory drugs in wastewaters and the environment: a review. Environ Chem Lett. https://doi. org/10.1007/s10311-020-01065-y

Evaluate Pharma (2017) World Preview 2017, Outlook to 2022. Eval Pharma 1-41
Pittura L, Avio CG, Regoli F et al (2018) The fate of microplastics in an Italian wastewater treatment plant. Sci Total Environ 652:602-610. https://doi.org/10.1016/j.scitotenv.2018.10.269

Prabakar D, Suvetha KS, Manimudi VT et al (2018) Pretreatment technologies for industrial effluents: critical review on bioenergy production and environmental concerns. J Environ Manage 218:165-180. https://doi.org/10.1016/j.jenvman.2018.03. 136

Product Stewardship Institute (2011) Report: Lessons learned: voluntary pharmaceutical take-back programs in the Great Lakes States, pp 1-6

Puckowski A, Mioduszewska K, Łukaszewicz P et al (2016) Bioaccumulation and analytics of pharmaceutical residues in the environment: a review. J Pharm Biomed Anal 127:232-255. https://doi. org/10.1016/j.jpba.2016.02.049

Qi C, Huang J, Wang B et al (2018) Contaminants of emerging concern in landfill leachate in China: a review. Emerg Contam 4:1-10. https://doi.org/10.1016/j.emcon.2018.06.001

Qu M, Lin Q, Huang L et al (2018) Dopamine-loaded blood exosomes targeted to brain for better treatment of Parkinson's disease. J Control Release 287:156-166. https://doi.org/10.1016/j.jconrel. 2018.08.035

Raju G, Sarkar P, Singla E et al (2016) Comparison of environmental sustainability of pharmaceutical packaging. Perspect Sci 8:683685. https://doi.org/10.1016/j.pisc.2016.06.058

Ramirez E, Brill J, Ohlhausen MK, Wright JD, McSweeny TP (2015) Competition in the pet medications industry: prescription and distribution practices. Federal Trade Comission, (May). Retrieved from https://www.ftc.gov/system/files/documents/ reports/competition-pet-medicationsindustry-prescription-porta bility-distribution-practices/150526-pet-meds-report.pdf

Rangel DEN, Finlay RD, Hallsworth JE et al (2018) Fungal strategies for dealing with environment- and agriculture-induced stresses. Fungal Biol 122:602-612. https://doi.org/10.1016/j.funbio.2018. 02.002

Rastogi T, Leder C, Kümmerer K (2015) Re-designing of existing pharmaceuticals for environmental biodegradability: a tiered approach with $\beta$-blocker propranolol as an example. Environ Sci Technol 49:11756-11763. https://doi.org/10.1021/acs.est. 5 b03051

Reddersen K, Heberer T (2002) Identification and significance of phenazone drugs and their metabolites in ground- and drinking water. Chemosphere 49:539-544

Regional Workshop for OIE National Focal Points (2017) Illegal veterinary medicines

Reichert JF, Souza DM, Martins AF (2019) Antipsychotic drugs in hospital wastewater and a preliminary risk assessment. Ecotoxicol Environ Saf 170:559-567. https://doi.org/10.1016/j.ecoenv. 2018.12.021

Ribeiro AR, Castro PML, Tiritan ME (2012) Chiral pharmaceuticals in the environment. Environ Chem Lett 10:239-253. https://doi. org/10.1007/s10311-011-0352-0

Robert F, Edel-Hermann V, Steinberg C et al (2016) Biological control of ornamental plant diseases caused by Fusarium oxysporum: a review. Biol Control 101:17-30. https://doi.org/10.1016/j.bioco ntrol.2016.06.004

European Medicine Agency (2014) Sales of veterinary antimicrobial agents in 29 European countries in 2014 Trends across 2011 to 2014 Sixth ESVAC report

Samadder SR, Prabhakar R, Khan D et al (2017) Analysis of the contaminants released from municipal solid waste landfill site: a case study. Sci Total Environ 580:593-601. https://doi.org/10.1016/j. scitotenv.2016.12.003

Sanchez W, Sremski W, Piccini B et al (2011) Adverse effects in wild fish living downstream from pharmaceutical manufacture 
discharges. Environ Int 37:1342-1348. https://doi.org/10.1016/j. envint.2011.06.002

Sanganyado E, Lu Z, Fu Q et al (2017) Chiral pharmaceuticals: a review on their environmental occurrence and fate processes. Water Res 124:527-542. https://doi.org/10.1016/j.watres.2017. 08.003

Sanguanrut P, Munkongwongsiri N, Kongkumnerd J et al (2018) A cohort study of 196 Thai shrimp ponds reveals a complex etiology for early mortality syndrome (EMS). Aquaculture 493:2636. https://doi.org/10.1016/j.aquaculture.2018.04.033

Santos L, Ramos F (2018) Antimicrobial resistance in aquaculture: current knowledge and alternatives to tackle the problem. Int $\mathrm{J}$ Antimicrob Agents 52:135-143. https://doi.org/10.1016/j.ijant imicag.2018.03.010

Santos LHMLM, Gros M, Rodriguez-Mozaz S et al (2013) Contribution of hospital effluents to the load of pharmaceuticals in urban wastewaters: identification of ecologically relevant pharmaceuticals. Sci Total Environ 461-462:302-316. https://doi.org/10. 1016/j.scitotenv.2013.04.077

Saxena SK, Rangasamy R, Krishnan AA et al (2018) Simultaneous determination of multi-residue and multi-class antibiotics in aquaculture shrimps by UPLC-MS/MS. Food Chem 260:336343. https://doi.org/10.1016/j.foodchem.2018.04.018

Schirmer K, Schirmer M (2008) Who is chasing whom? A call for a more integrated approach to reduce the load of micro-pollutants in the environment. Water Sci Technol 57:145-150. https://doi. org/10.2166/wst.2008.826

Scott TM, Phillips PJ, Kolpin DW et al (2018) Pharmaceutical manufacturing facility discharges can substantially increase the pharmaceutical load to U.S. wastewaters. Sci Total Environ 636:6979. https://doi.org/10.1016/j.scitotenv.2018.04.160

Sercombe L, Veerati T, Moheimani F et al (2015) Advances and challenges of liposome assisted drug delivery. Front Pharmacol 6:1-13. https://doi.org/10.3389/fphar.2015.00286

Serrano PH (2005) Responsible use of antibiotics in aquaculture. Food Agric Organ United Nations 91:1-101

Shah A, Shah M (2020) Characterisation and bioremediation of wastewater: a review exploring bioremediation as a sustainable technique for pharmaceutical wastewater. Groundw Sustain Dev 11:100383. https://doi.org/10.1016/j.gsd.2020.100383

Shi X, Leong KY, Ng HY (2017) Anaerobic treatment of pharmaceutical wastewater: a critical review. Bioresour Technol 245:12381244. https://doi.org/10.1016/j.biortech.2017.08.150

Shyong YJ, Chang KC, Lin FH (2018) Calcium phosphate particles stimulate exosome secretion from phagocytes for the enhancement of drug delivery. Colloids Surf B Biointerfaces 171:391397. https://doi.org/10.1016/j.colsurfb.2018.07.037

Sigurnjak Bureš M, Cvetnić M, Miloloža M et al (2021) Modeling the toxicity of pollutants mixtures for risk assessment: a review. Environ Chem Lett. https://doi.org/10.1007/s10311-020-01107-5

Singh R, Das MM, Sumana G et al (2014) Biosensors for pathogen detection: a smart approach towards clinical diagnosis. Sens Actuators, B Chem 197:385-404. https://doi.org/10.1016/j.snb. 2014.03.005

Smirnova M, Owens JGG (2017) Medicalized addiction, self-medication, or nonmedical prescription drug use? How trust figures into incarcerated women's conceptualization of illicit prescription drug use. Soc Sci Med 183:106-115. https://doi.org/10.1016/j. socscimed.2017.04.047

Soe ZC, Thapa RK, Ou W et al (2018) Folate receptor-mediated celastrol and irinotecan combination delivery using liposomes for effective chemotherapy. Colloids Surf B Biointerfaces 170:718728. https://doi.org/10.1016/j.colsurfb.2018.07.013

Soleimanifar H, Deng Y, Wu L, Sarkar D (2016) Water treatment residual (WTR)-coated wood mulch for alleviation of toxic metals and phosphorus from polluted urban stormwater runoff. Chemosphere 154:289-292. https://doi.org/10.1016/j.chemosphere. 2016.03.101

Stadlmair LF, Letzel T, Drewes JE, Grassmann J (2018) Enzymes in removal of pharmaceuticals from wastewater: a critical review of challenges, applications and screening methods for their selection. Chemosphere 205:649-661. https://doi.org/10.1016/j. chemosphere.2018.04.142

Stepnowski P, Wolecki D, Puckowski A et al (2020) Anti-inflammatory drugs in the Vistula River following the failure of the Warsaw sewage collection system in 2019. Sci Total Environ 745:140848. https://doi.org/10.1016/j.scitotenv.2020.140848

Sun B, Luo C, Cui W et al (2017) Chemotherapy agent-unsaturated fatty acid prodrugs and prodrug-nanoplatforms for cancer chemotherapy. J Control Release 264:145-159. https://doi.org/ 10.1016/j.jconrel.2017.08.034

Tang K, Spiliotopoulou A, Chhetri RK et al (2019) Removal of pharmaceuticals, toxicity and natural fluorescence through the ozonation of biologically-treated hospital wastewater, with further polishing via a suspended biofilm. Chem Eng J 359:321-330. https://doi.org/10.1016/j.cej.2018.11.112

Tiwari B, Sellamuthu B, Ouarda Y et al (2017) Review on fate and mechanism of removal of pharmaceutical pollutants from wastewater using biological approach. Bioresour Technol 224:1-12. https://doi.org/10.1016/j.biortech.2016.11.042

Tong AYC, Peake BM, Braund R (2011a) Disposal practices for unused medications around the world. Environ Int 37:292-298. https:// doi.org/10.1016/j.envint.2010.10.002

Tong AYC, Peake BM, Braund R (2011b) Disposal practices for unused medications in New Zealand community pharmacies. J Prim Health Care 3:197-203. https://doi.org/10.1016/j.envint. 2010.10.002

Torres NF, Chibi B, Middleton LE et al (2018) Evidence of factors influencing self-medication with antibiotics in LMICs: a systematic scoping review protocol. Syst Rev 7:92-101. https://doi.org/ 10.1186/s13643-018-0758-x

Tran N, Drogui P, Brar SK (2015a) Sonochemical techniques to degrade pharmaceutical organic pollutants. Environ Chem Lett 13:251-268. https://doi.org/10.1007/s10311-015-0512-8

Tran NH, Yew-Hoong Gin K, Ngo HH (2015b) Fecal pollution source tracking toolbox for identification, evaluation and characterization of fecal contamination in receiving urban surface waters and groundwater. Sci Total Environ 538:38-57. https://doi.org/10. 1016/j.scitotenv.2015.07.155

United Nations Environment Programme (2019) Global Chemicals Outlook II

Uppu DSSM, Ghosh C, Haldar J (2015) Surviving sepsis in the era of antibiotic resistance: are there any alternative approaches to antibiotic therapy? Microb Pathog 80:7-13. https://doi.org/10. 1016/j.micpath.2015.02.001

van de Ven K, Koenraadt R (2017) Exploring the relationship between online buyers and sellers of image and performance enhancing drugs (IPEDs): quality issues, trust and self-regulation. Int $\mathbf{J}$ Drug Policy 50:48-55. https://doi.org/10.1016/j.drugpo.2017. 09.004

Vatovec C, Van Wagoner E, Evans C (2017) Investigating sources of pharmaceutical pollution: survey of over-the-counter and prescription medication purchasing, use, and disposal practices among university students. J Environ Manage 198:348-352. https://doi.org/10.1016/j.jenvman.2017.04.101

Vellinga A, Cormican S, Driscoll J et al (2014) Public practice regarding disposal of unused medicines in Ireland. Sci Total Environ 478:98-102. https://doi.org/10.1016/j.scitotenv.2014.01.085 
Vermeulen LC, van Hengel M, Kroeze C et al (2019) Cryptosporidium concentrations in rivers worldwide. Water Res 149:202-214. https://doi.org/10.1016/j.watres.2018.10.069

Vezzaro L, Benedetti L, Gevaert V et al (2014) A model library for dynamic transport and fate of micropollutants in integrated urban wastewater and stormwater systems. Environ Model Softw 53:98-111. https://doi.org/10.1016/j.envsoft.2013.11.010

Wagil M, Kumirska J, Stolte S et al (2014) Development of sensitive and reliable LC-MS/MS methods for the determination of three fluoroquinolones in water and fish tissue samples and preliminary environmental risk assessment of their presence in two rivers in northern Poland. Sci Total Environ 493:1006-1013. https://doi. org/10.1016/j.scitotenv.2014.06.082

Wagil M, Maszkowska J, Białk-Bielińska A et al (2015) Determination of metronidazole residues in water, sediment and fish tissue samples. Chemosphere 119:28-34. https://doi.org/10.1016/j.chemo sphere.2013.12.061

Walther R, Rautio J, Zelikin AN (2017) Prodrugs in medicinal chemistry and enzyme prodrug therapies. Adv Drug Deliv Rev 118:6577. https://doi.org/10.1016/j.addr.2017.06.013

Wang Q, Wang P, Yang Q (2018) Occurrence and diversity of antibiotic resistance in untreated hospital wastewater. Sci Total Environ 621:990-999. https://doi.org/10.1016/j.scitotenv.2017.10.128

Wang A, Ran C, Wang Y et al (2019) Use of probiotics in aquaculture of China - a review of the past decade. Fish Shellfish Immunol 86:734-755. https://doi.org/10.1016/j.fsi.2018.12.026

Wang Z, Walker GW, Muir DCG, Nagatani-Yoshida K (2020) Toward a global understanding of chemical pollution: a first comprehensive analysis of national and regional chemical inventories. Environ Sci Technol 54:2575-2584. https://doi.org/10.1021/acs. est.9b06379

Wenzel H, Larsen HF, Clauson-Kaas J et al (2008) Weighing environmental advantages and disadvantages of advanced wastewater treatment of micro-pollutants using environmental life cycle assessment. Water Sci Technol 57:27-32. https://doi.org/10. 2166/wst.2008.819

Wiest J, Saedtler M, Balk A et al (2017) Mapping the pharmaceutical design space by amorphous ionic liquid strategies. J Control Release 268:314-322. https://doi.org/10.1016/j.jconrel.2017.10. 040

Williams M, Kookana RS, Mehta A et al (2019) Emerging contaminants in a river receiving untreated wastewater from an Indian urban centre. Sci Total Environ 647:1256-1265. https://doi.org/ 10.1016/j.scitotenv.2018.08.084

World Health Organization (2014) Antimicrobial Resistance, Global Report on Surveillance

Xiang J, Wu M, Lei J et al (2018) The fate and risk assessment of psychiatric pharmaceuticals from psychiatric hospital effluent. Ecotoxicol Environ Saf 150:289-296. https://doi.org/10.1016/j. ecoenv.2017.12.049

Xu M, Bai X, Pei L, Pan H (2016) A research on application of water treatment technology for reclaimed water irrigation. Int J Hydrog Energy 41:15930-15937. https://doi.org/10.1016/j.ijhydene. 2016.05.020

Xu Y, Xue X, Dong L et al (2018) Long-term dynamics of leachate production, leakage from hazardous waste landfill sites and the impact on groundwater quality and human health. Waste Manag 82:156-166. https://doi.org/10.1016/j.wasman.2018.10.009

Yi X, Tran NH, Yin T et al (2017) Removal of selected PPCPs, EDCs, and antibiotic resistance genes in landfill leachate by a full-scale constructed wetlands system. Water Res 121:46-60. https://doi. org/10.1016/j.watres.2017.05.008

Yin H, Xie M, Zhang L et al (2019) Identification of sewage markers to indicate sources of contamination: low cost options for misconnected non-stormwater source tracking in stormwater systems. Sci Total Environ 648:125-134. https://doi.org/10.1016/j.scito tenv.2018.07.448

You X, Wu D, Wei H et al (2018) Fluoroquinolones and B-lactam antibiotics and antibiotic resistance genes in autumn leachates of seven major municipal solid waste landfills in China. Environ Int 113:162-169. https://doi.org/10.1016/j.envint.2018.02.002

Zepon Tarpani RR, Azapagic A (2018) Life cycle environmental impacts of advanced wastewater treatment techniques for removal of pharmaceuticals and personal care products (PPCPs). J Environ Manage 215:258-272. https://doi.org/10.1016/j.jenvm an.2018.03.047

Zhang Q, Li X (2007) Pharmacokinetics and residue elimination of oxytetracycline in grass carp, Ctenopharyngodon idellus. Aquaculture 272:140-145. https://doi.org/10.1016/j.aquaculture.2007. 08.033

Zhang Z, Zheng X, Chen Y et al (2015) Public perception and acceptability toward reclaimed water in Tianjin. Resour Conserv Recycl 104:291-299. https://doi.org/10.1016/j.resconrec.2015.07.013

Zhang Q, Hu J, Lee DJJ et al (2017) Sludge treatment: current research trends. Bioresour Technol 243:1159-1172. https://doi.org/10. 1016/j.biortech.2017.07.070

Zhao R, Feng J, Yin X et al (2018) Antibiotic resistome in landfill leachate from different cities of China deciphered by metagenomic analysis. Water Res 134:126-139. https://doi.org/10.1016/j. watres.2018.01.063

Zhao F, Ju F, Huang K et al (2019) Comprehensive insights into the key components of bacterial assemblages in pharmaceutical wastewater treatment plants. Sci Total Environ 651:2148-2157. https:// doi.org/10.1016/j.scitotenv.2018.10.101

Zhi S, Zhou J, Yang F et al (2018) Systematic analysis of occurrence and variation tendency about 58 typical veterinary antibiotics during animal wastewater disposal processes in Tianjin, China. Ecotoxicol Environ Saf 165:376-385. https://doi.org/10.1016/j. ecoenv.2018.08.101

Zhou Z, Xu P, Cao X et al (2016) Efficiency promotion and its mechanisms of simultaneous nitrogen and phosphorus removal in stormwater biofilters. Bioresour Technol 218:842-849. https:// doi.org/10.1016/j.biortech.2016.07.039

Zhou Y, Wu S, Zhou H et al (2018) Chiral pharmaceuticals: environment sources, potential human health impacts, remediation technologies and future perspective. Environ Int 121:523-537. https://doi.org/10.1016/j.envint.2018.09.041

Zou S, Xu W, Zhang R et al (2011) Occurrence and distribution of antibiotics in coastal water of the Bohai Bay, China: impacts of river discharge and aquaculture activities. Environ Pollut 159:2913-2920. https://doi.org/10.1016/j.envpol.2011.04.037

Publisher's Note Springer Nature remains neutral with regard to jurisdictional claims in published maps and institutional affiliations. 